\title{
Synthesis, biological evaluation and docking analysis of a new series of methylsulfonyl and sulfamoyl acetamides and ethyl acetates as potent COX-2 inhibitors
}

\author{
Sara Consalvi ${ }^{a}$, Salvatore Alfonso ${ }^{\mathrm{a}}$, Angela Di Capua ${ }^{\mathrm{b}}$, Giovanna Poce ${ }^{\mathrm{a}, *}$, Adele Pirolli ${ }^{\mathrm{c}}$, \\ Manuela Sabatino ${ }^{c}$, Rino Ragno ${ }^{c}$, Maurizio Anzini ${ }^{\mathrm{b}}$, Stefania Sartini ${ }^{\mathrm{d}}$, Concettina La Motta ${ }^{\mathrm{d}}$, \\ Lorenzo Di Cesare Mannelli $^{\mathrm{e}}$, Carla Ghelardini ${ }^{\mathrm{e}}$, Mariangela Biava ${ }^{\mathrm{a}}$ \\ a Dipartimento di Chimica e Tecnologie del Farmaco, Università degli Studi di Roma 'La Sapienza', Piazzale Aldo Moro 5, 00185 Roma, Italy \\ ${ }^{\mathrm{b}}$ Dipartimento di Biotecnologie, Chimica e Farmacia, Università degli Studi di Siena, Via A. De Gasperi, 2, 53100 Siena, Italy \\ ${ }^{\mathrm{c}}$ Rome Center for Molecular Design, Dipartimento di Chimica e Tecnologie del Farmaco, Università degli Studi di Roma 'La Sapienza', Piazzale Aldo Moro 5, 00185 Roma, Italy \\ ${ }^{\mathrm{d}}$ Dipartimento di Farmacia, Università di Pisa, via Bonanno Pisano 6, 56126 Pisa, Italy \\ ${ }^{\text {e } D i p a r t i m e n t o ~ d i ~ N e u r o l o g i a, ~ P s i c o l o g i a, ~ A r e a ~ d e l ~ F a r m a c o ~ e ~ S a l u t e ~ d e l ~ B a m b i n o, ~ U n i v e r s i t a ̀ ~ d e g l i ~ S t u d i ~ d i ~ F i r e n z e, ~ V i a l e ~ G . ~ P i e r a c c i n i ~ 6, ~ I-50139 ~ F i r e n z e, ~ I t a l y ~}$
}

\section{A R T I C L E I N F O}

\section{Article history}

Received 4 November 2014

Revised 14 December 2014

Accepted 17 December 2014

Available online 26 December 2014

\section{Keywords}

COX-2 inhibitors

Analgesic agents

Anti-inflammatory agents

Diarylpyrroles

Medicinal chemistry

\begin{abstract}
A B S T R A C T
We report herein the synthesis, biological evaluation and docking analysis of a new series of methylsulfonyl, sulfamoyl acetamides and ethyl acetates that selectively inhibit cyclooxygenase-2 (COX-2) isoform. Among the newly synthesized compounds, some of them were endowed with a good activity against COX-2 and a good selectivity COX-2/COX-1 in vitro as well as a desirable analgesic activity in vivo, proving that replacement of the ester moiety with an amide group gave access to more stable derivatives, characterized by a good COX-inhibition.
\end{abstract}

(c) 2015 Elsevier Ltd. All rights reserved.

\section{Introduction}

Cyclooxygenase (COX) enzyme plays a central role in the biosynthetic pathway of important biological mediators called prostanoids from arachidonic acid (AA). Although there are different isoforms of COX (named COX-1 and COX-2) encoded by different genes, there is a high homology sequence content in the derived proteins (both isoforms share about $60 \%$ amino acid sequence). ${ }^{1}$ The most important differences between COX-1 and COX-2 are at biological levels. While COX-1 is a constitutive enzyme, COX-2 is mostly undetectable in tissues in normal conditions, while it is induced during inflammation, hypoxia, and in many cancers. ${ }^{1,2}$

Abbreviations: AA, arachidonic acid; CMC, carboxymethylcellulose; COX, cyclooxygenase; Coxibs, COX-2 selective inhibitors; Das, accuracies percentages; DIPA, diisopropylamine; DMAP, dimethylaminopyridine; EDCI, 1-ethyl-3-(3-dimethylaminopropyl)carbodiimide; EIA, enzyme immunoassay; ip, intraperitoneal; PGE2a, prostaglandin E2a; RMSDs, root mean square deviations; t-NSAIDs, traditional nonsteroidal anti-inflammatory drug; TBAF, tetra- $n$-butylammonium fluoride.

* Corresponding author. Tel.: +3906 4991 0000; fax: +39 0649913133.

E-mail address: giovanna.poce@uniroma1.it (G. Poce).
Traditional non-steroidal anti-inflammatory drugs (t-NSAIDs) can inhibit both COX-1 and COX-2 and are associated with a consistent risk of serious adverse events, related to COX-1 inhibition. While inflammation is reduced, stomach upset as well as ulceration and bleeding can be caused by the loss of the stomach lining. ${ }^{3}$

COX-2 selective inhibitors (Coxibs), such as celecoxib and rofecoxib, have been developed with the aim of reducing gastric irritation. ${ }^{3}$ Though, rofecoxib $\left(\right.$ Vioxx $\left.^{\circledR}\right)$ and valdecoxib (Bextra $\left.{ }^{\circledR}\right)$ were withdrawn from the market because of an increased incidence of thrombotic events associated with long-term use. ${ }^{4}$

Nevertheless, some studies have suggested that rofecoxib's adverse cardiac events may be related to its chemical structure. In fact, rofecoxib can readily form a reactive metabolite, which in turn can disrupt essential cellular structure by reacting with nucleophilic groups of various biologic molecules, ${ }^{5}$ suggesting that adverse cardiac events might not be a class-related effect. Therefore, novel scaffolds with selective COX-2 inhibitory activity are needed.

We have previously reported several studies on the design, synthesis and activity of pyrrole-based COX-2 inhibitors. ${ }^{6-12}$ 
These compounds showed selective inhibition towards COX-2 with $\mathrm{IC}_{50}$ in the nanomolar range. However, their in vivo profile, was somehow lower than expected, indicating that the chemical and enzymatic liability of these esters play a crucial role in the pharmacokinetic fate of such a class of molecules. ${ }^{10}$ Therefore, we present herein our efforts on developing more stable compounds by replacing the ester moiety with an amide one.

At first, we have prepared propyl and isopropyl acetic amides 1-4 (Fig. 1) bearing a $N 1$ phenyl ring decorated either at position 3 or position 4 with a fluorine atom, and a C5 $p$-methylsulfonyl phenyl as reminiscent of previously synthesized compounds. ${ }^{11}$ Moreover, sulfamoylphenyl compounds 5-12 (Fig. 1), have also been synthesized. The sulfamoylphenyl group has been introduced grounding on the fact that several studies suggest that arylsulfonamides generally display a greater in vivo profile compared to that of the corresponding aryl sulfones probably because the $\operatorname{lower} \log P$ contributes to improved absorption and bioavailability. ${ }^{13}$ In particular, compounds 5 and $\mathbf{6}$ (Fig. 1) bearing a decorated N1 phenyl ring, a C5 sulfamoylphenyl moiety and an acetic ester chain at position 3 have been prepared in order to evaluate the difference in activity that could be given by the sulfamoyl moiety with respect to acetic amides 1-4. Acetic amides 9-12 (Fig. 1) have been then designed and synthesized by combining the introduction of the sulfamoylphenyl moiety with the amide function. Finally, considering that both ester and amide derivatives could give rise in vivo to the formation of corresponding acids, compounds 7 and $\mathbf{8}$ (Fig. 1) have been prepared and tested.

Compounds 1-12 were evaluated in vitro for their ability to inhibit both COX-1 and COX-2 via an enzyme immunoassay (EIA) and data were rationalized through docking simulations. Finally, the analgesic activities of compounds 1-12 were evaluated in an in vivo model of inflammatory pain. ${ }^{14}$

\section{Results and discussion}

\subsection{Synthesis}

Compounds 1-4 have been prepared according to the synthetic pathway shown in Scheme 1. Briefly, 4-sulfonmethylphenyl acetic acids 13a,b were obtained following the procedure previously described. ${ }^{10}$ The coupling stage which led to acetamides 1-4 was afforded in the presence of EDCI and DMAP and the appropriate amine.

Compounds 5-12 have been synthesized according to the synthetic pathway shown in Scheme 2. Briefly, pyrroles 14a,b have been prepared as previously described. ${ }^{10}$ Generation of the carbanion with butyllithium on aryl methyl sulfones $\mathbf{1 4 a}, \mathbf{b}$, followed by addition of iodomethyltrimethylsilane gave the trimethylsilylethyl sulfone intermediates 15a,b. Desilylation with tetrabutylammonium fluoride to the sulfinic acid salts followed by treatment with

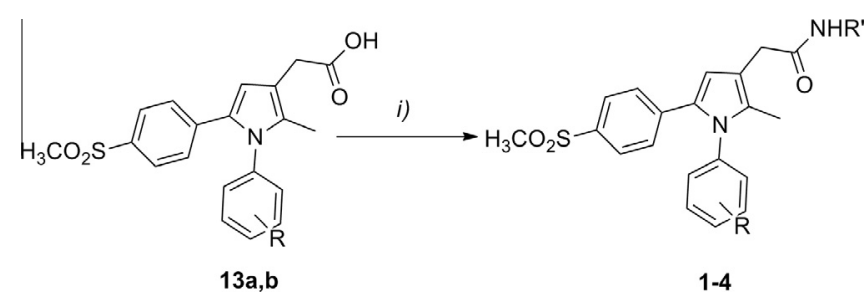

Scheme 1. Synthesis of compounds 1-4. Reagents and conditions: (i) EDCI, DMAP, $\mathrm{CH}_{2} \mathrm{Cl}_{2}$, amine, rt, $15 \mathrm{~h}$.

hydroxylamine-O-sulfonic acid in the microwave apparatus, gave the desired arylsulfonamides $\mathbf{1 6 a}, \mathbf{b}$. Construction of the $\mathrm{C} 3$ acetic chain of $\mathbf{5}$ and $\mathbf{6}$ was achieved by the regioselective acylation of $\mathbf{1 6 a}, \mathbf{b}$ with ethoxalyl chloride and titanium tetrachloride followed by reduction with triethylsilane in trifluoroacetic acid. Hydrolysis with $\mathrm{NaOH}$ afforded acetic acids $\mathbf{7}$ and $\mathbf{8}$. Finally, 4-sulfamoylphenyl acetamides 9-12 were afforded by means of EDCI as activating agent and DMAP as covalent nucleophilic catalyst, then the active species were reacted with the appropriate amine.

\subsection{Biological and pharmacological studies}

All the synthesized compounds were tested in vitro to assess their inhibitory activities towards both cyclooxygenases (COX-1 and COX-2). Tests were performed exploiting the commercially available COX Inhibitor Screening Assay (Cayman Chemical Company, Ann Arbor, MI, USA), which quantifies prostanoids produced by reaction between $\mathrm{COX}$ and arachidonic acid via an enzyme immunoassay. The inhibitory efficacy of the novel derivatives was routinely estimated at concentration of $10 \mu \mathrm{M}$, and those compounds found to be active were then tested at different concentrations between $10 \mu \mathrm{M}$ and $10 \mathrm{nM}$, to determine their $\mathrm{IC}_{50}$ values. As shown in Table 1, some of the newly synthesized compounds proved to inhibit COX-2 to a certain extent when tested at $10 \mu \mathrm{M}$. Within the methylsulfonylphenyl series (1-4), the presence of the isopropylamide fragment determined the highest inhibitory efficacy, as compounds $\mathbf{3}$ and $\mathbf{4}$ turned out to be more potent than the propylamide counterparts, $\mathbf{1}$ and $\mathbf{2}$. In the sulfamoylphenyl series, the highest inhibitory activity was guaranteed by the presence of the ethyl ester function. Actually, compounds $\mathbf{5}\left(\mathrm{IC}_{50}\right.$ $0.92 \pm 0.05 \mu \mathrm{M})$ and $6\left(\mathrm{IC}_{50} 1.07 \pm 0.05 \mu \mathrm{M}\right)$ proved to be potent inhibitors. Hydrolysis of the ester moiety, to afford acetic acid derivatives $\mathbf{7}$ and $\mathbf{8}$, and the replacement with an amide fragment, as in compounds 9-12, lowered the observed efficacy against the target protein. The most effective compounds 4-6 and 9, showed no appreciable inhibitory properties against $\mathrm{COX}-1$, thus proving to be selective inhibitors of the inducible form of this enzyme.

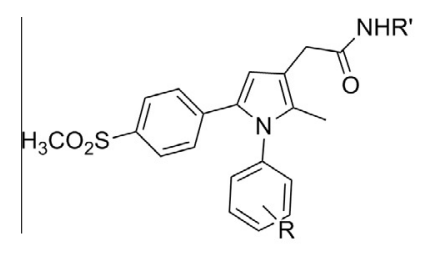

1-4

1: $\mathrm{R}=3-\mathrm{F} ; \mathrm{R}^{\prime}=-\mathrm{C}_{3} \mathrm{H}_{7}$

2: $\mathrm{R}=4-\mathrm{F} ; \mathrm{R}^{\prime}=-\mathrm{C}_{3} \mathrm{H}_{7}$

3: $\mathrm{R}=3-\mathrm{F} ; \mathrm{R}^{\prime}=-{ }^{i} \mathrm{C}_{3} \mathrm{H}_{7}$

4: $\mathrm{R}=4-\mathrm{F} ; \mathrm{R}^{\prime}={ }_{-}^{-} \mathrm{C}_{3} \mathrm{H}_{7}$

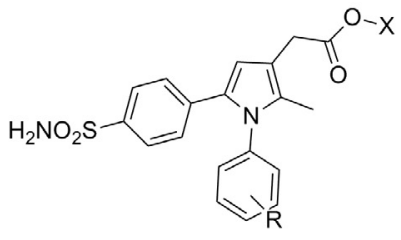

5-8

5: $\mathrm{R}=3-\mathrm{F} ; \mathrm{X}=-\mathrm{C}_{2} \mathrm{H}_{5}$

6: $R=4-F ; X=-C_{2} H_{5}$

7: $R=3-F ; X=H$

8: $R=4-F ; X=H$

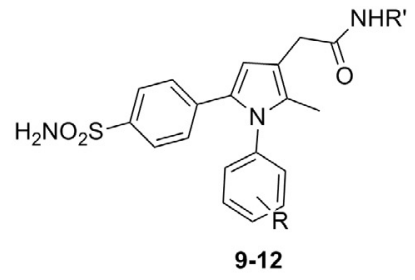

9: $\mathrm{R}=3-\mathrm{F} ; \mathrm{R}^{\prime}=-\mathrm{C}_{3} \mathrm{H}_{7}$

10: $\mathrm{R}=4-\mathrm{F} ; \mathrm{R}^{\prime}=-\mathrm{C}_{3} \mathrm{H}_{7}$

11: $\mathrm{R}=3-\mathrm{F} ; \mathrm{R}^{\prime}=-{ }^{i} \mathrm{C}_{3} \mathrm{H}_{7}$

12: $\mathrm{R}=4-\mathrm{F} ; \mathrm{R}^{\prime}={ }_{-}{ }^{i} \mathrm{C}_{3} \mathrm{H}_{7}$

Figure 1. Chemical structures of compounds 1-12. 
<smiles>[R]c1ccc(-n2c(C)ccc2-c2ccc(S(C)(=O)=O)cc2)cc1</smiles>

$14 a, b$<smiles>[R]c1ccc(-n2c(C)ccc2-c2ccc(S(O)(O)CC[Si](C)(C)C)cc2)cc1</smiles>

$15 a, b$

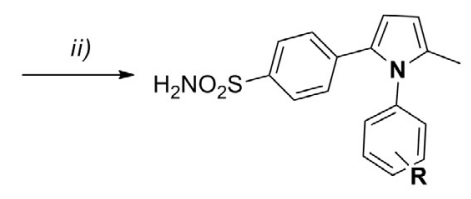<smiles>[124In]</smiles><smiles>[R6]c1cccc(-n2c(-c3ccc(S(N)(=O)=O)cc3)cc(CC(=O)O)c2C)c1</smiles><smiles></smiles>

$17 a, b$<smiles>[R]NC(=O)Cc1cc(-c2ccc(S(N)(=O)=O)cc2)n(-c2ccc[R]([R])c2)c1C</smiles>

Scheme 2. Synthesis of compounds 5-12. Reagents and conditions: (i) $n$-BuLi, DIPA, THF, $-78{ }^{\circ} \mathrm{C}, 30 \mathrm{~min}$, then iodomethyltrimethylsilane, rt, $1.5 \mathrm{~h}$; (ii) TBAF, hexane, $15 \mathrm{~min}$, MW ( $120^{\circ} \mathrm{C}, 150 \mathrm{~W}, 170 \mathrm{psi}$ ), then NaAc, hydroxylamine-O-sulfonic acid, $10 \mathrm{~min}, \mathrm{MW}\left(50^{\circ} \mathrm{C}, 150 \mathrm{~W}, 170 \mathrm{psi}\right)$; (iii) EtOCOCOCl, $\mathrm{TiCl}_{4}, \mathrm{CH}_{2} \mathrm{Cl}_{2}, \mathrm{rt}^{2} 4 \mathrm{~h}$; (iv) Et $\mathrm{SiH}_{3} \mathrm{TFA}, \mathrm{rt}, 2 \mathrm{~h}$; (v) $1 \mathrm{~N} \mathrm{NaOH}, \mathrm{MeOH}$, reflux, $2 \mathrm{~h}$; (vi) EDCI, DMAP, $\mathrm{CH}_{2} \mathrm{Cl}_{2}$, amine, rt, $15 \mathrm{~h}$.

Table 1

In vitro inhibition of COX-1 and COX-2 by compounds 1-12

\begin{tabular}{|c|c|c|c|}
\hline \multirow[t]{2}{*}{ Compd } & \multicolumn{2}{|c|}{$\%$ of Inhibition $(10 \mu \mathrm{M})$} & \multirow[t]{2}{*}{$\mathrm{IC}_{50}\left(\mathrm{COX}-2, \mu \mathrm{M}^{\mathrm{a}}\right)$} \\
\hline & COX-1 & COX-2 & \\
\hline 1 & n.t. ${ }^{b}$ & 43 & n.d. ${ }^{\mathrm{c}}$ \\
\hline 2 & n.t. ${ }^{b}$ & 65 & n.d. ${ }^{\mathrm{c}}$ \\
\hline 3 & n.t. ${ }^{b}$ & 74 & $7.00 \pm 0.34$ \\
\hline 4 & 36 & 95 & $4.91 \pm 0.20$ \\
\hline 5 & n.a. ${ }^{d}$ & 89 & $0.92 \pm 0.05$ \\
\hline 6 & n.a. ${ }^{\mathrm{d}}$ & 82 & $1.07 \pm 0.05$ \\
\hline 7 & n.t. ${ }^{b}$ & 65 & n.d. ${ }^{c}$ \\
\hline 8 & n.t. ${ }^{b}$ & 65 & n.d. ${ }^{\mathrm{c}}$ \\
\hline 9 & n.a. ${ }^{d}$ & 96 & $5.78 \pm 0.30$ \\
\hline 10 & n.t. & 62 & n.d. ${ }^{\mathrm{c}}$ \\
\hline 11 & n.t. ${ }^{b}$ & 49 & n.d. ${ }^{\mathrm{C}}$ \\
\hline 12 & n.t. ${ }^{b}$ & 48 & n.d. ${ }^{\mathrm{C}}$ \\
\hline SC $-560^{15}$ & 100 & - & - \\
\hline DuP-697 16 & - & 100 & - \\
\hline
\end{tabular}

${ }^{a} \mathrm{IC}_{50}$ values, means $\pm \mathrm{SD}$, represent the concentration required to produce $50 \%$ enzyme inhibition.

$\mathrm{b}$ Not tested.

c Not determined.

d Not active, no inhibition was observed at $10 \mu \mathrm{M}$ of test compound.

The analgesic activities of compounds 1-12 were evaluated in an in vivo model of inflammatory pain ${ }^{14}$ by measuring the reduction of writhes induced by intra-peritoneal injections of acetic acid solution in mice. Compounds 1-12 were orally administered (po) (1$40 \mathrm{mg} / \mathrm{kg}$ dose range) $30 \mathrm{~min}$ before the induction of writhes. Results are reported as the number of writhes and as a percentage of writhes reduction with respect to vehicle-treated mice in Table 2.

Compound $6\left(\mathrm{R}=4-\mathrm{F} ; \mathrm{X}=-\mathrm{C}_{2} \mathrm{H}_{5}\right)$ showed the best efficacy in inducing writhes reduction (62\%) when dosed at $40 \mathrm{mg} / \mathrm{kg}$, while its efficacy was dose dependent within the range of $10-40 \mathrm{mg} /$ $\mathrm{kg}$. The meta-fluoro analog $\mathbf{5}$, which showed similar activity in vitro, was much less effective in reducing the number of writhes in vivo. The same trend can be seen for the acids $\mathbf{7}$ and $\mathbf{8}$. In the methylsulfonyl phenyl series (1-4), compound $\mathbf{4}$ proved to be the best one in reducing the number of writhes (48.7\%), it is possible to observe a significant decrease of activity when going from isopropyl to propyl amides ( 3 and $\mathbf{4}$ vs $\mathbf{1}$ and 2 ), this could depend on the fact that a more branched chain is more stable at metabolic level. Finally, sulfamoylphenyl acetamides 9-12 proved a moderate efficacy in reducing the number of writhes with the exception of compound 9. In fact, nonetheless it proved to be the best compound within the sulfamoylphenyl series in vitro $\left(\mathrm{IC}_{50}\right.$ $5.78 \pm 0.30 \mu \mathrm{M})$ it showed nearly the lowest activity in vivo with only $12 \%$ of writhes reduction.

\subsection{Structure-based studies}

\subsubsection{Docking assessment}

Before performing any docking study, the most suitable docking program within a series of 8 program/scoring combinations function was assessed by a previously described cross-docking proto$\mathrm{col}^{17,18}$ applied on the available experimental co-crystallized complexes for either COX-1 (18 complexes, Table 3) or COX-2 (14 complexes, Table 4). Briefly, each energy minimized COX complex was divided into ligand and protein (see Section 4). The separated ligand conformations were randomized and docked into all proteins (cross-docking), except for the native ones. The resulting lowest energy pose within all the docking runs were then compared to the experimental ones, and the root mean square deviations (RMSDs) were calculated (Tables 1 and 2). The calculated docking accuracy percentages (DAs\%) ${ }^{19}$ revealed Surflex-Dock ${ }^{20,21}$ as the most suitable program to dock a modeled ligand into COX-1 showing DAs\% of 58.33 while Vina performed the best for COX-2 (DA\% =67.86). In the case of COX-1, Autodock performed the same DA\%, but the error dispersion as calculated by the RMSD standard deviation was slightly higher than that of displayed by Surflex-Dock, with almost the same average values, furthermore Surflex-Dock is about 10 times faster than Autodock. These results clearly indicate that in the presence of a ligand able to bind either COX-1 or COX-2, the most suitable program need to be chosen adhoc. Based on the docking assessment Surflex-Dock and Vina were able to suggest their correct binding mode with the lowest errors for COX-1 and COX-2, respectively. 
Table 2

Effect of 1-12, celecoxib, and vehicle (CMC) in the mouse abdominal constriction test (acetic acid 0.6\%)

\begin{tabular}{|c|c|c|c|c|}
\hline Treatment & No. of mice & Dose (mg/kg po) & No. or writhes & Writhes reduction (\%) \\
\hline CMC & 28 & & $30.4 \pm 1.6$ & \\
\hline 1 & 5 & 10 & $26.7 \pm 2.5$ & 12.2 \\
\hline 1 & 5 & 30 & $27.4 \pm 3.3$ & 9.9 \\
\hline 2 & 6 & 1 & $30.6 \pm 3.7$ & - \\
\hline 2 & 7 & 3 & $27.3 \pm 2.9$ & 10.2 \\
\hline 2 & 6 & 10 & $21.3 \pm 3.4^{*}$ & 29.9 \\
\hline 3 & 5 & 10 & $29.3 \pm 2.8$ & 3.6 \\
\hline 3 & 5 & 30 & $22.7 \pm 2.9^{*}$ & 25.3 \\
\hline 4 & 6 & 10 & $26.7 \pm 3.6$ & 12.2 \\
\hline 4 & 5 & 30 & $15.6 \pm 3.2^{*}$ & 48.7 \\
\hline 5 & 5 & 10 & $22.5 \pm 2.5^{\wedge}$ & 26.0 \\
\hline 5 & 5 & 30 & $20.16 \pm 2.8^{*}$ & 33.5 \\
\hline 6 & 8 & 10 & $29.2 \pm 3.1$ & 10.4 \\
\hline 6 & 8 & 20 & $24.5 \pm 3.6^{*}$ & 24.8 \\
\hline 6 & 8 & 40 & $12.3 \pm 2.5^{*}$ & 62.3 \\
\hline 7 & 5 & 10 & $27.5 \pm 2.8$ & 9.5 \\
\hline 7 & 6 & 30 & $31.3 \pm 3.3$ & - \\
\hline 8 & 7 & 10 & $27.1 \pm 3.5$ & 16.9 \\
\hline 8 & 8 & 20 & $21.8 \pm 3.2^{*}$ & 33.1 \\
\hline 8 & 9 & 40 & $16.63 \pm 3.1^{*}$ & 49.1 \\
\hline 9 & 5 & 10 & $32.9 \pm 4.2$ & - \\
\hline 9 & 5 & 30 & $26.7 \pm 3.7$ & 12.2 \\
\hline 10 & 6 & 3 & $29.2 \pm 3.3$ & 3.9 \\
\hline 10 & 5 & 10 & $27.9 \pm 4.1$ & 8.3 \\
\hline 10 & 6 & 30 & $18.5 \pm 3.6^{*}$ & 39.1 \\
\hline 11 & 6 & 3 & $26.9 \pm 3.1$ & 11.5 \\
\hline 11 & 5 & 10 & $21.5 \pm 3.2^{*}$ & 29.3 \\
\hline 11 & 5 & 30 & $20.8 \pm 3.3^{*}$ & 31.6 \\
\hline 12 & 6 & 3 & $25.5 \pm 3.8$ & 16.1 \\
\hline 12 & 5 & 10 & $19.3 \pm 2.5^{*}$ & 36.5 \\
\hline 12 & 6 & 30 & $17.1 \pm 3.5^{*}$ & 43.7 \\
\hline Celecoxib & 12 & 10 & $12.96 \pm 2.1^{*}$ & 57.4 \\
\hline
\end{tabular}

^ $P<0.05$.

${ }^{*} P<0.01$ in comparison with CMC treated group.

Table 3

Docking assessment for COX-1

\begin{tabular}{|c|c|c|c|c|c|c|c|c|}
\hline \multirow[t]{2}{*}{$\mathrm{PDB}^{\mathrm{a}}$} & \multicolumn{3}{|c|}{ Plants } & \multirow[t]{2}{*}{ Surflex-Dock } & \multirow[t]{2}{*}{ Vina } & \multirow[t]{2}{*}{ Autodock } & \multicolumn{2}{|c|}{ Paradocks } \\
\hline & Chemplp $^{\mathrm{e}}$ & $\mathrm{Plp95}^{\mathrm{e}}$ & $\mathrm{plp}^{\mathrm{e}}$ & & & & Pscore $^{e}$ & Pmf04 \\
\hline $2 A Y L$ & 1.87 & 3.45 & 3.23 & 0.64 & 0.66 & 0.60 & 3.18 & 0.45 \\
\hline $1 \mathrm{CQE}$ & 1.08 & 3.82 & 3.54 & 0.44 & 1.71 & 1.67 & 3.41 & 0.46 \\
\hline 1DIY & 0.92 & 11.15 & 3.68 & 1.21 & 3.15 & 3.87 & 3.48 & 3.31 \\
\hline $1 \mathrm{EBV}$ & 4.38 & 4.27 & 4.38 & 2.29 & 4.02 & 13.71 & 4.31 & 6.38 \\
\hline $1 \mathrm{EQG}$ & 0.59 & 7.19 & 4.20 & 0.53 & 6.56 & 0.66 & 3.06 & 1.80 \\
\hline $1 \mathrm{EQH}$ & 0.67 & 3.75 & 3.71 & 1.70 & 3.16 & 0.75 & 3.37 & 0.50 \\
\hline 1FE2 & 1.47 & 3.82 & 1.43 & 10.18 & 1.39 & 1.52 & 17.83 & 1.90 \\
\hline 1HT5 & 3.97 & 3.99 & 3.97 & 1.95 & 3.15 & 1.91 & 3.03 & 0.91 \\
\hline 1HT8 & 0.91 & 7.14 & 7.14 & 1.98 & 4.68 & 2.18 & 4.06 & 4.65 \\
\hline 1PGE & 7.10 & 7.27 & 7.11 & 0.86 & 1.67 & 4.50 & 4.18 & 2.70 \\
\hline 1PGF & 6.58 & 6.56 & 6.57 & 5.47 & 3.28 & 3.27 & 3.71 & 2.63 \\
\hline 1PGG & 6.90 & 3.55 & 3.56 & 6.18 & 3.55 & 3.56 & 6.63 & 6.50 \\
\hline 1PTH & 7.27 & 7.67 & 7.27 & 3.97 & 7.25 & 1.06 & 8.35 & 8.35 \\
\hline 2OYE & 2.39 & 2.36 & 2.10 & 4.12 & 2.84 & 2.25 & 3.65 & 3.11 \\
\hline $2 O Y U$ & 4.22 & 4.25 & 4.27 & 5.37 & 2.88 & 2.38 & 2.45 & 5.38 \\
\hline $3 N 8 W$ & 3.10 & 3.72 & 3.37 & 0.54 & 2.86 & 0.64 & 2.94 & 0.89 \\
\hline $3 N 8 X$ & 0.74 & 5.93 & 5.95 & 4.82 & 4.89 & 6.72 & 1.05 & 0.99 \\
\hline $3 N 8 Z$ & 0.63 & 3.68 & 3.43 & 1.67 & 1.74 & 1.62 & 3.18 & 0.41 \\
\hline DA $\%^{\mathrm{b}}$ & 52.78 & 2.78 & 8.33 & 58.33 & 36.11 & 58.33 & 11.11 & 55.56 \\
\hline Average $^{c}$ & 3.04 & 5.20 & 4.38 & 3.00 & 3.30 & 2.94 & 4.55 & 2.85 \\
\hline StDev $^{\mathrm{d}}$ & 2.49 & 2.21 & 1.72 & 2.62 & 1.72 & 3.13 & 3.67 & 2.45 \\
\hline
\end{tabular}

All values are reported as RMSD.

a PDB entry codes.

b Docking accuracy as defined in the Section 4.

c Average RMSD value.

d Standard deviation value.

e The scoring function names as implemented in the docking programs. 
Table 4

Docking assessment for COX-2

\begin{tabular}{|c|c|c|c|c|c|c|c|c|}
\hline \multirow[t]{2}{*}{$\mathrm{PDB}^{\mathrm{a}}$} & \multicolumn{3}{|c|}{ Plants } & \multirow[t]{2}{*}{ Surflex-Dock } & \multirow[t]{2}{*}{ Vina } & \multirow[t]{2}{*}{ Autodock } & \multicolumn{2}{|c|}{ Paradocks } \\
\hline & Chemplp $^{\mathrm{e}}$ & $\mathrm{Plp95}^{\mathrm{e}}$ & $\mathrm{plp}^{\mathrm{e}}$ & & & & Pscore ${ }^{\mathrm{e}}$ & Pmf04 \\
\hline $1 \mathrm{PXX}$ & 6.79 & 6.942 & 5.783 & 5.72 & 7.60 & 5.73 & 1.68 & 1.32 \\
\hline 3LN0 & 0.76 & 0.764 & 1.529 & 5.28 & 1.16 & 5.25 & 1.18 & 1.15 \\
\hline 3LN1 & 1.05 & 0.915 & 0.631 & 0.83 & 0.83 & 1.05 & 0.83 & 0.90 \\
\hline $3 \mathrm{MQE}$ & 4.78 & 4.489 & 4.492 & 6.16 & 3.00 & 6.66 & 4.82 & 0.95 \\
\hline 3NT1 & 0.28 & 0.586 & 0.323 & 0.49 & 0.29 & 0.76 & 0.68 & 6.67 \\
\hline 3NTB & 0.64 & 4.5 & 0.471 & 1.88 & 0.73 & 0.62 & 6.47 & 1.23 \\
\hline $3 N T G$ & 3.60 & 4.538 & 3.71 & 1.02 & 3.74 & 1.04 & 3.75 & 3.23 \\
\hline 3Q7D & 0.36 & 4.886 & 1.923 & 0.14 & 0.59 & 0.29 & 6.31 & 6.47 \\
\hline 3QMO & 0.89 & 1.09 & 0.907 & 1.03 & 0.72 & 5.07 & 0.92 & 1.03 \\
\hline 3RR3 & 0.68 & 0.718 & 1.006 & 0.54 & 0.46 & 0.99 & 1.73 & 1.60 \\
\hline $4 \mathrm{E} 1 \mathrm{G}$ & 7.03 & 6.809 & 6.923 & 8.98 & 6.91 & 5.65 & 14.83 & 11.31 \\
\hline 4FM5 & 1.78 & 1.777 & 2.072 & 0.44 & 1.80 & 1.65 & 0.90 & 0.37 \\
\hline $4 \mathrm{M} 10$ & 7.25 & 7.276 & 5.834 & 1.77 & 1.45 & 7.40 & 7.61 & 1.96 \\
\hline 4M11 & 7.27 & 7.378 & 7.328 & 5.65 & 5.20 & 8.32 & 7.32 & 6.90 \\
\hline DA \% & 57.14 & 42.86 & 53.57 & 64.29 & 67.86 & 50.00 & 50.00 & 64.29 \\
\hline Average $^{c}$ & 3.08 & 3.76 & 3.07 & 2.85 & 2.46 & 3.60 & 4.22 & 3.22 \\
\hline StDev $^{\mathrm{d}}$ & 2.91 & 2.71 & 2.55 & 2.87 & 2.48 & 2.93 & 4.03 & 3.29 \\
\hline
\end{tabular}

All values are reported as RMSD.

a PDB entry codes.

b Docking accuracy as defined in the Section 4.

c Average RMSD value.

d Standard deviation value.

e The scoring function names as implemented in the docking programs.

\subsubsection{Binding mode analysis of the new compounds}

As Surflex-Dock and Vina performed the best, the titled compounds were all cross-docked by means of these programs. In particular, all the compounds found active against either COX-1 or COX-2 enzymes (Tables 1 and 5) were modeled and cross-docked into all the available COX-1/COX-2 experimental structures following the same protocol as in the docking assessment. The lowest energy poses were selected ${ }^{17}$ as the likely binding modes for the newly synthesized compounds. Compound $\mathbf{4}$ was the only one found with an appreciable inhibitory activity against COX-1 (36\% at $10 \mu \mathrm{M}$ ) and its lowest energy bound pose was found in the proteins 2OYU (Fig. 2A). On the contrary, all the compounds were selectively active against COX-2 at different levels and therefore were all cross-docked. Eight times (compounds 1, 2, 6, 7, 8, 9, 10 and 11, Fig. 2B) out of twelve, 3LNI was the preferred binding site, while three times (compounds 3, 4 and 12, Fig. 2C) was selected the protein extracted from the $2 \mathrm{MQE}$ complex and compound $\mathbf{5}$ was found to best bind in 3QMO (Fig. 2D). As a matter of fact, the Vina predicted affinities against COX-2 for compounds 4, 5, 6 and $\mathbf{9}$ did not correlate with the experimental ones listed in Table 1 , likely due to the high redundancy in the scoring function associated to any docking program. On the other hand, comparing the Vina average predicted affinities, the scoring function correctly indicated compound 4 as more active against COX-2 than against COX-1 (Table 4). In the latter case, the enzymes' structural differences are somehow recognized by the scoring function and corroborate the previous statement. COX-2 active compounds were all docked, and their bindings examined. As shown in Figure 2B-D the COX-2 active derivatives $\mathbf{1 - 1 2}$ share a common binding mode (BM). Being compound 4 the only one exerting some activity against either enzyme BM inspection into COX-1 and COX-2 were focused on this compound. Nevertheless BM analysis revealed that compound $\mathbf{4}$ adopt similar binding modes into either isoenzyme. The main difference in binding relies on the fact that in COX-2 Arg513 side chain in the selectivity pocket ${ }^{5}$ makes a moderate hydrogen bond ${ }^{22}$ with the sulfonyl group (distance NCOX-2Arg513•••O4- $\left(\mathrm{SO}_{2}\right)=3.10 \AA$, Fig. 3 ), which is missing in COX-1 being residue 513 an histidine with a shorter and less flexible side chain not able to make any hydrogen bond with 4-sulfonyl group. Surprisingly, this observation is in good agreement with the $1.23 \mathrm{kcal} / \mathrm{mol}$ binding energy difference recorded for compound 4 in both $\mathrm{COX}-1$ and $\mathrm{COX}-2$ (Table 5). Furthermore, the $4-\mathrm{SO}_{2}$ hydrogen bonding oxygen is perfectly superimposing its analog atom in Celecoxib $\mathrm{SO}_{2}$ moiety as found in the bound crystal (PDB entry code 3LNI, Fig. 3). Regarding the other titled derivatives, the overall binding modes are quite overlapping, and any further inspection would be redundant (Fig. 2). This common BM confirms the reproducibility of the docking protocol when slightly structural differences occur. The herein application of Surflex-Dock/Vina and the cross-docking protocol are in good agreement with the earlier observations in which a different docking program (Autodock 3.0.5) and only one COX-2 structure (pdb entry code 1CX2) were used. For comparison purposes, the latest version of Autodock was applied in a parallel to cross-dock 1-12 and only slightly binding mode differences were observed (not shown).

Table 5

Predicted average affinities for compounds docked compounds in COX-1/COX-2 enzymes

\begin{tabular}{|c|c|c|c|c|}
\hline Compd & Preferred COX1 protein PDB code & Average predicted activity ( $\mathrm{kcal} / \mathrm{mol})$ & Preferred COX2 protein PDB code & Average predicted activity $(\mathrm{kcal} / \mathrm{mol})$ \\
\hline 4 & $2 O Y U$ & $-5.57^{* *}$ & $3 \mathrm{MQE}$ & -6.80 \\
\hline 5 & $\mathrm{ND}^{*}$ & - & 3QMO & -7.82 \\
\hline 6 & $\mathrm{ND}^{*}$ & - & 3LN1 & -7.59 \\
\hline 9 & $\mathrm{ND}^{*}$ & - & 3LN1 & -8.20 \\
\hline
\end{tabular}

In the COX-1 and COX-2 column are reported the compounds' preferred binding sites PDB codes.

* ND: not docked.

** Surflex-Dock pose rescored by Vina. 


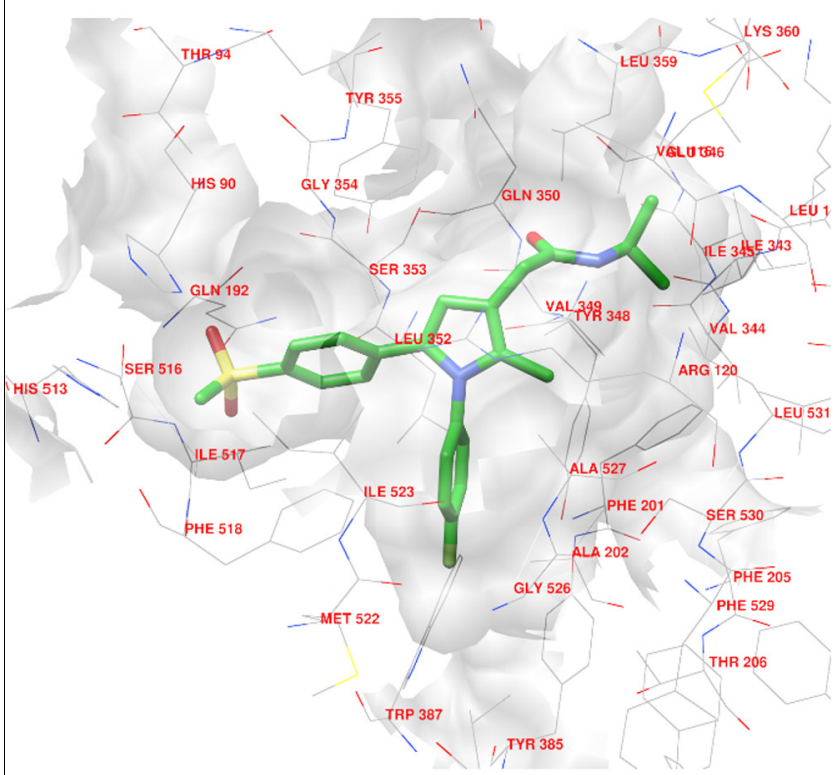

$\mathbf{A}$

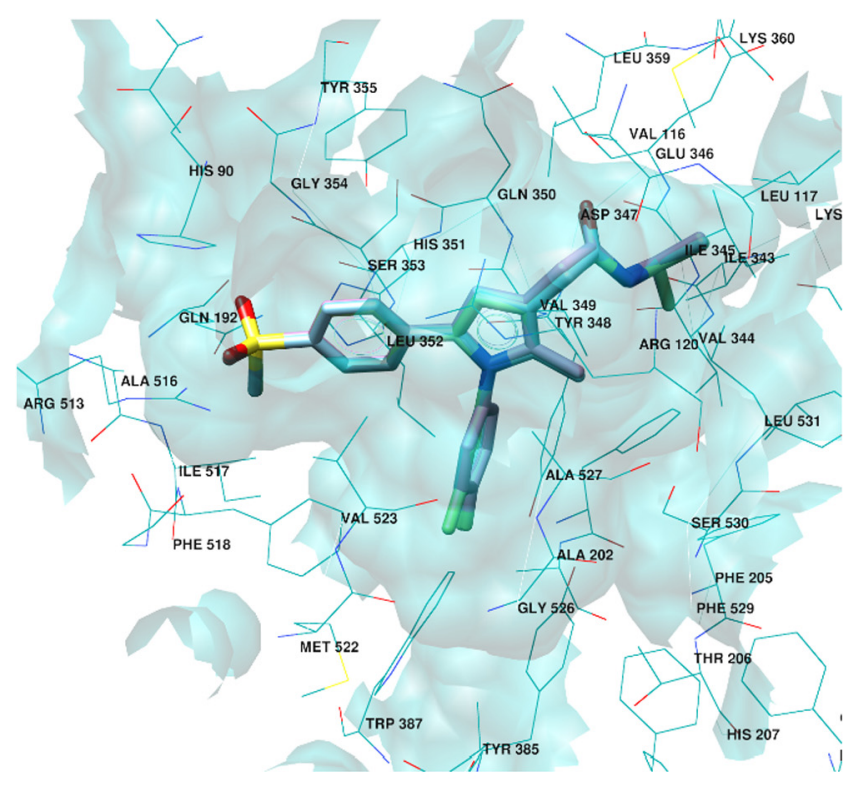

C

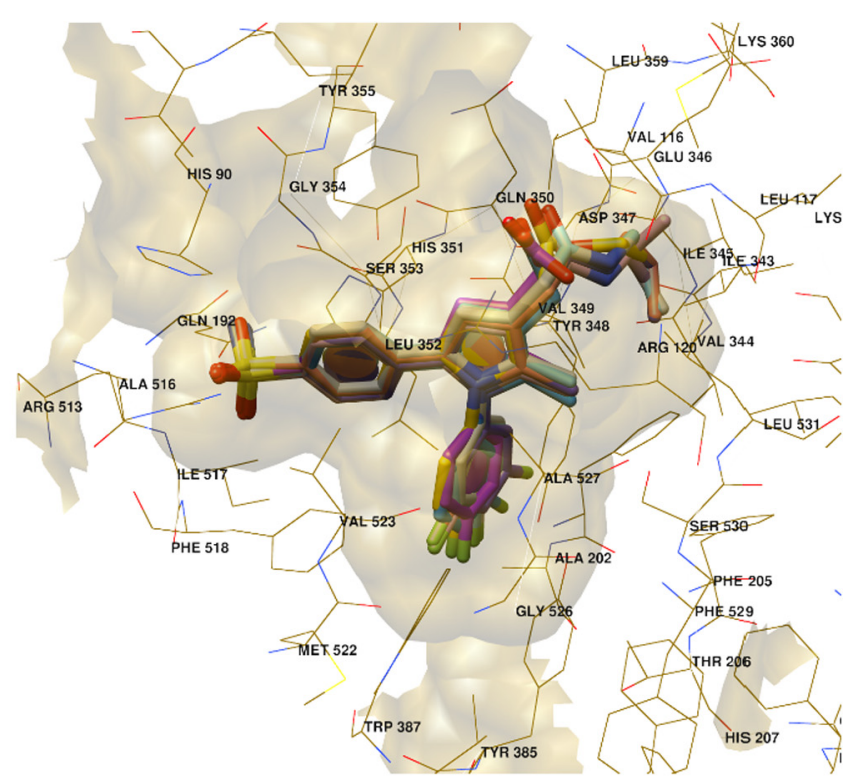

B

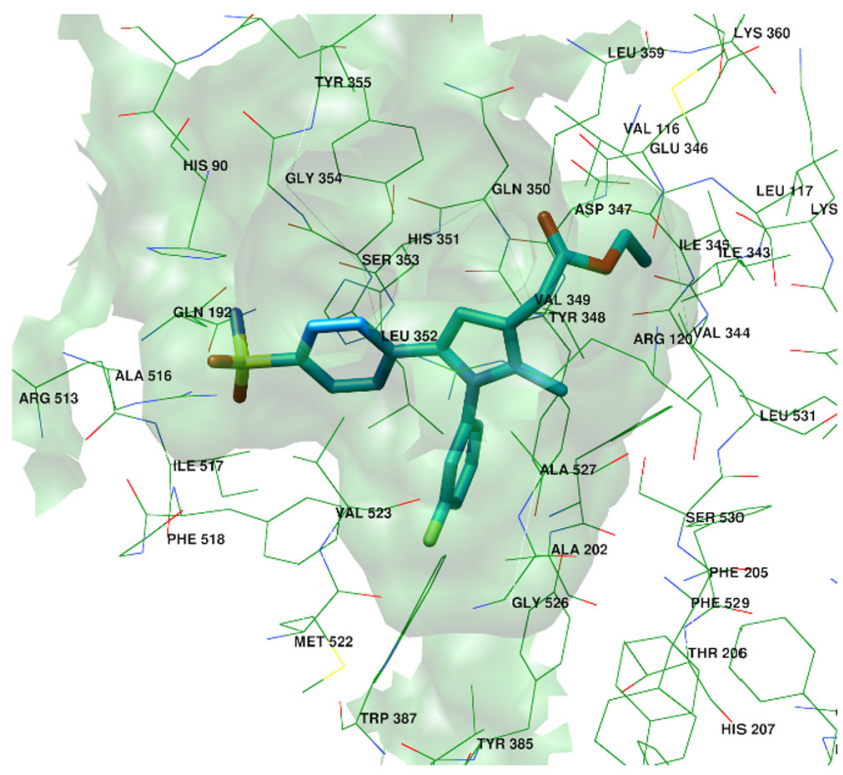

D

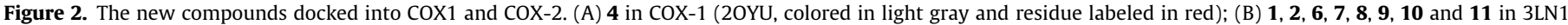

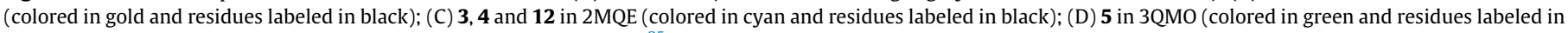
black). The figures were generated by the means of UCSF Chimera $1.9 .^{25}$

\section{Conclusions}

The development of a novel class of COX-2 selective inhibitors has been reported. Among the newly synthesized compounds, some of them were endowed with a good activity against COX-2 and a good selectivity COX-2/COX-1 in vitro and showed a good analgesic activity in vivo, proving that replacement of the ester moiety with an amide group gave access to more stable derivatives, characterized by a good COX-inhibiting profile. Comparing the same dosage $(10 \mathrm{mg} / \mathrm{kg})$, sulfamoyl phenyl derivatives proved to be more active than the methylsulfonyl analogues, showing that the introduction of this group led to compounds characterized by a better in vivo profile and a greater activity at lower dosages, probably because of their improved bioavailability. Further studies are needed to evaluate the influence of that moiety on solubility and to assess the pharmacokinetic profile.

Finally, binding mode analyses on compound 1-12 to COX-2 confirmed the structure-based studies performed on pyrrole derivatives we previously reported. The cross-docking protocol employed as much as possible the available experimental structural information representing the basis for future applications such as development of predictive 3-D QSAR and/or COMBINEr 


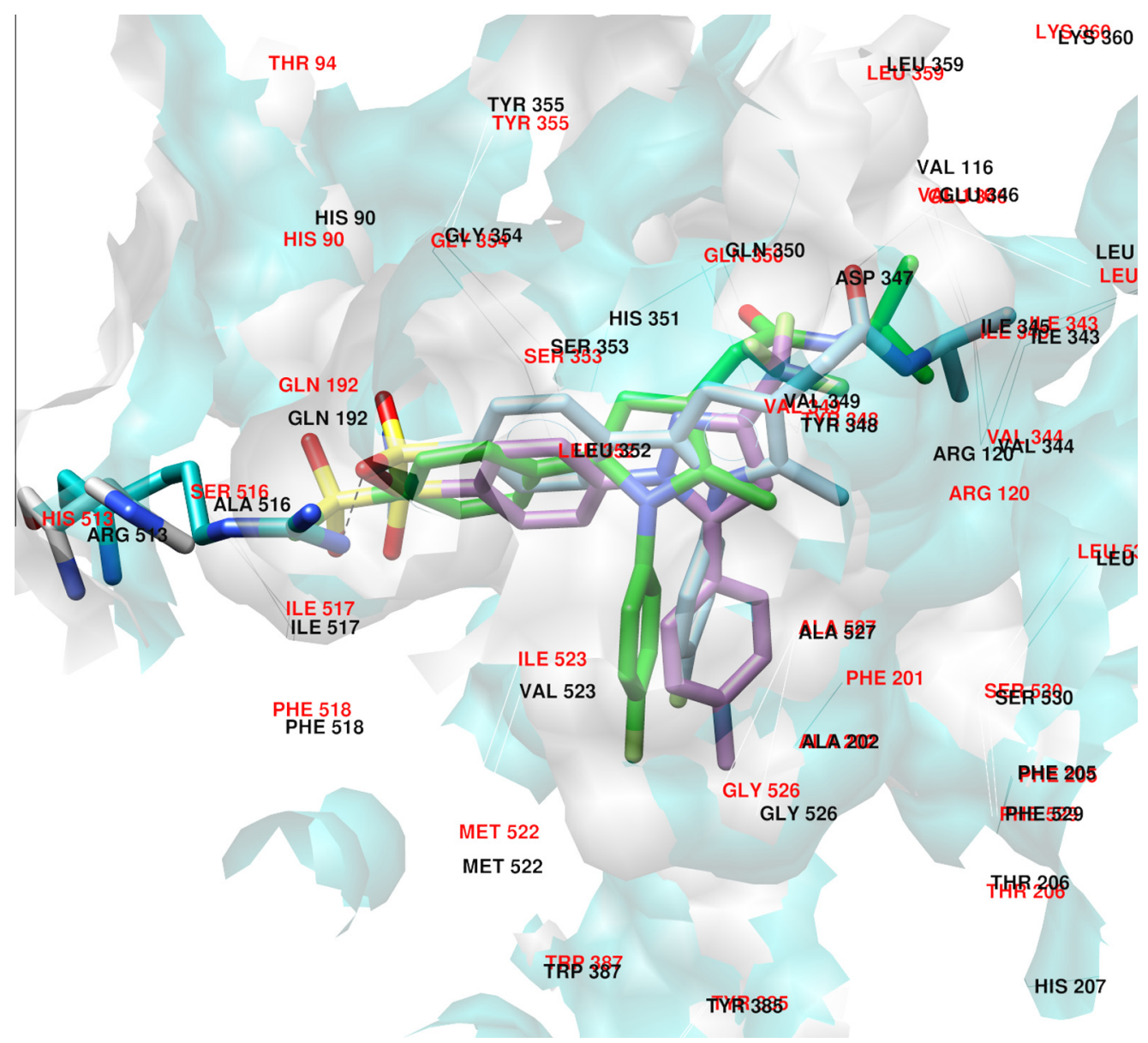

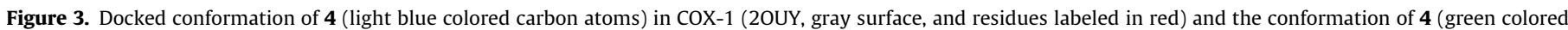

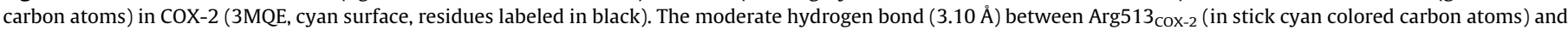

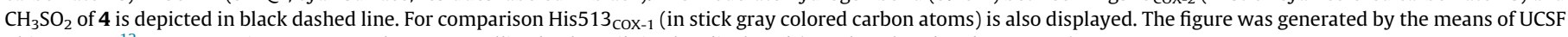
Chimera 1.9. ${ }^{12}$ For comparison purpose, the co-crystallized celecoxib is also displayed (purple colored carbon atoms).

models. $^{23,24}$ The latter, could be used as external scoring functions to fill the lack of correct activity prediction trend by the associated docking program scoring function.

\section{Experimental section}

\subsection{Chemistry}

All chemicals used were of reagent grade. Yields refer to purified products and are not optimized. A CEM Discovery microwave system apparatus was used for microwaved reactions. Melting points were determined in open capillaries on a Gallenkamp apparatus and were uncorrected. Sigma-Aldrich silica gel 60 (230400 mesh) was used for column chromatography. Merck TLC plates (silica gel $60 \mathrm{~F}$ 254) were used for thin-layer chromatography (TLC). ${ }^{13} \mathrm{C}$ NMR and ${ }^{1} \mathrm{H}$ NMR spectra were recorded with a Bruker AC 400 spectrometer in the indicated solvent (TMS as the internal standard). The values of the chemical shifts are expressed in $\delta$. Mass spectra were recorded on an API-TOF Mariner by Perspective Biosystem (Stratford, Texas, USA).

\subsubsection{General procedure for the preparation of 4-methylsulfonylphenyl acetamides 1-4}

To a solution of the appropriate acid $(\mathbf{1 3 a}, \mathbf{b})(0.51 \mathrm{mmol})$ in DCM $(10 \mathrm{~mL})$, the suitable amine $(2.04 \mathrm{mmol})$, DMAP $(0.61 \mathrm{mmol}$, $00.07 \mathrm{~g})$ and $\mathrm{EDCI}(0.82 \mathrm{mmol}, 0.16 \mathrm{~g})$ were added in sequence.
The reaction mixture was stirred at room temperature for $15 \mathrm{~h}$ then diluted with water, and the two phases were separated with dichloromethane. The organic layers were washed with $2 \mathrm{~N}$ $\mathrm{HCl}, \mathrm{NaHCO}_{3}$ saturated solution and brine, and then dried over $\mathrm{Na}_{2} \mathrm{SO}_{4}$, filtered and concentrated in vacuo. The obtained crude products were purified by column chromatography on silica gel using cyclohexane/ethyl acetate $1: 1(\mathrm{v} / \mathrm{v})$, as eluent. After recrystallization from ethyl acetate the desired products 1-4 were obtained.

4.1.1.1. 2-(1-(3-Fluorophenyl)-2-methyl-5-(4-(methylsulfonyl) phenyl)-1H-pyrrol-3-yl)- $N$-propylacetamide (1). White powder, mp $164{ }^{\circ} \mathrm{C}$ (yield 80\%). ${ }^{1} \mathrm{H}$ NMR (400 MHz, DMSO- $\left.d_{6}\right) \delta$ ppm: $7.87(\mathrm{t}, 1 \mathrm{H}, \mathrm{NH}), 7.68(\mathrm{~d}, 2 \mathrm{H},-\mathrm{C}-\mathrm{CH}-\mathrm{CH}), 7.51-7.46(\mathrm{~m}, 1 \mathrm{H}$, $\mathrm{CH}-\mathrm{CH}-\mathrm{CH}), 7.31-7.29(\mathrm{~m}, 1 \mathrm{H}, \mathrm{C}-\mathrm{CH}-\mathrm{CH}), 7.27-7.25(\mathrm{~m}, 1 \mathrm{H}, \mathrm{N}-$ $\mathrm{C}-\mathrm{CH}-\mathrm{C}-\mathrm{F}), 7.18$ (d, 2H, S-C-CH-CH), 7.04 (d, 1H, CH-CH-C-F), $6.51\left(\mathrm{~s}, 1 \mathrm{H}, \mathrm{CH}\right.$ pyrrolic), $3.24\left(\mathrm{~s}, 2 \mathrm{H}, \mathrm{C}-\mathrm{CH}_{2}-\mathrm{CO}\right), 3.14$ (s, $\left.3 \mathrm{H}, \mathrm{CH}_{3}-\mathrm{SO}_{2}\right), 3.01\left(\mathrm{~m}, 2 \mathrm{H}, \mathrm{N}-\mathrm{CH}_{2}-\mathrm{CH}_{2}\right), 2.02$ (s, 3H, $\mathrm{CH}_{3}$ pyrrolic), 1.44-1.39 (sest, $\left.2 \mathrm{H}, \mathrm{CH}_{2}-\mathrm{CH}_{2}-\mathrm{CH}_{3}\right), 0.84\left(\mathrm{t}, 3 \mathrm{H}, \mathrm{CH}_{2}-\mathrm{CH}_{3}\right) .{ }^{13} \mathrm{C}$ NMR (100 MHz, DMSO- $\left.d_{6}\right) \delta(\mathrm{ppm}): 171.6(\mathrm{CH}-\mathrm{CO}-\mathrm{NH}), 161.4$ (C-F), $144.4(\mathrm{CH}-\mathrm{C}-\mathrm{CH}), 143.7(\mathrm{~N}-\mathrm{C}-\mathrm{CH}), 141.3(\mathrm{~S}-\mathrm{C}), 134.6$ (N-C-C), $131.2(\mathrm{CH}-\mathrm{CH}-\mathrm{CH}), 128.8(\mathrm{CH}-\mathrm{C}-\mathrm{S}), 128.4(\mathrm{CH}-\mathrm{CH}-\mathrm{C})$, $125.8\left(\mathrm{~N}-\mathrm{C}-\mathrm{CH}_{3}\right), \quad 121.0 \quad\left(\mathrm{CH}-\mathrm{C}-\mathrm{CH}_{2}\right), \quad 116.3(\mathrm{C}-\mathrm{CH}-\mathrm{CH})$, 113.5 ( $\mathrm{CH}$ pyrrolic), 112.7 ( $\mathrm{CH}-\mathrm{C}-\mathrm{C}-\mathrm{F}), 107.2(\mathrm{~F}-\mathrm{C}-\mathrm{CH}-\mathrm{C}-\mathrm{N})$, $47.3\left(\mathrm{CH}_{3}-\mathrm{SO}_{2}\right), 42.6\left(\mathrm{NH}-\mathrm{CH}_{2}\right), 34.0\left(\mathrm{CH}_{2} \mathrm{CO}\right), 23.4\left(\mathrm{CH}_{2} \mathrm{CH}_{2} \mathrm{CH}_{3}\right)$, $14.6\left(\mathrm{CH}_{2}-\mathrm{CH}_{3}\right), \quad 10.0 \quad\left(\mathrm{CH}_{3}\right.$ pyrrolic $) . \quad$ MS-ESI: $\mathrm{m} / \mathrm{z} \quad 451.15$ $[\mathrm{M}+\mathrm{Na}]^{+}$. 
4.1.1.2. 2-(1-(4-Fluorophenyl)-2-methyl-5-(4-(methylsulfonyl) phenyl)-1H-pyrrol-3-yl)- $\mathrm{N}$-propylacetamide (2). White powder, mp $168{ }^{\circ} \mathrm{C}$ (yield 80\%). ${ }^{1} \mathrm{H}$ NMR (400 MHz, DMSO- $\left.d_{6}\right) \delta$ ppm: 7.86 (t, 1H, NH), 7.69 (d, 2H, $-\mathrm{C}-\mathrm{CH}-\mathrm{CH}), 7.32-7.30$ (m, 4H, $H$ aromatic), 7.19 (d, 2H, S-C-CH-CH), 6.52 (s, 1H, CH pyrrolic), 3.26 (s, $2 \mathrm{H}, \mathrm{C}-\mathrm{CH}_{2}-\mathrm{CO}$ ), 3.15 (s, $\left.3 \mathrm{H}, \mathrm{CH}_{3}-\mathrm{SO}_{2}\right), 3.03\left(\mathrm{~m}, 2 \mathrm{H}, \mathrm{N}-\mathrm{CH}_{2}-\mathrm{CH}_{2}\right)$, 2.01 (s, $3 \mathrm{H}, \mathrm{CH}_{3}$ pyrrolic), $1.45-1.41$ (sest, $2 \mathrm{H}, \mathrm{CH}_{2}-\mathrm{CH}_{2}-\mathrm{CH}_{3}$ ), $0.86\left(\mathrm{t}, 3 \mathrm{H}, \mathrm{CH}_{2}-\mathrm{CH}_{3}\right) .{ }^{13} \mathrm{C}$ NMR $\left(100 \mathrm{MHz}, \mathrm{DMSO}-d_{6}\right) \delta(\mathrm{ppm})$ : $171.6(\mathrm{CH}-\mathrm{CO}-\mathrm{NH}), 159.2(\mathrm{C}-\mathrm{F}), 146.2(\mathrm{~N}-\mathrm{C}-\mathrm{CH}), 144.0(\mathrm{CH}-\mathrm{C}-$ $\mathrm{CH}), 141.3(\mathrm{~S}-\mathrm{C}), 134.0,(\mathrm{~N}-\mathrm{C}-\mathrm{C}), 128.6(\mathrm{CH}-\mathrm{C}-\mathrm{S}), 128.0(\mathrm{CH}-\mathrm{CH}-$ C), $125.8\left(\mathrm{~N}-\mathrm{C}-\mathrm{CH}_{3}\right), 121.9(\mathrm{CH}-\mathrm{CH}-\mathrm{C}-\mathrm{N}), 121.2\left(\mathrm{CH}-\mathrm{C}-\mathrm{CH}_{2}\right)$, 115.8 ( $\mathrm{CH}-\mathrm{CH}-\mathrm{C}-\mathrm{F}), 112.9$ ( $\mathrm{CH}$ pyrrolic), $46.3\left(\mathrm{CH}_{3}-\mathrm{SO}_{2}\right), 41.9$ (NH-CH$), 34.3\left(\mathrm{CH}_{2} \mathrm{CO}\right), 23.1\left(\mathrm{CH}_{2} \mathrm{CH}_{2} \mathrm{CH}_{3}\right), 11.00\left(\mathrm{CH}_{2}-\mathrm{CH}_{3}\right), 9.8$ $\left(\mathrm{CH}_{3}\right.$ pyrrolic). MS-ESI: $\mathrm{m} / z 451.15[\mathrm{M}+\mathrm{Na}]^{+}$.

4.1.1.3. 2-(1-(3-Fluorophenyl)-2-methyl-5-(4-(methylsulfonyl) phenyl)-1H-pyrrol-3-yl)- $\boldsymbol{N}$-isopropylacetamide (3). White powder, mp $175{ }^{\circ} \mathrm{C}$ (yield 80\%). ${ }^{1} \mathrm{H}$ NMR (400 MHz, DMSO- $\left.d_{6}\right) \delta$ ppm: 7.80 (d, $1 \mathrm{H}, \mathrm{NH}), 7.69$ (d, 2H, $-\mathrm{C}-\mathrm{CH}-\mathrm{CH}), 7.51-7.46(\mathrm{~m}, 1 \mathrm{H}$, $\mathrm{CH}-\mathrm{CH}-\mathrm{CH}), 7.30-7.26(\mathrm{~m}, 1 \mathrm{H}, \mathrm{C}-\mathrm{CH}-\mathrm{CH}), 7.24-7.21(\mathrm{~m}, 1 \mathrm{H}, \mathrm{N}-$ $\mathrm{C}-\mathrm{CH}-\mathrm{C}-\mathrm{F}) 7.17$ (d, 2H, S-C-CH-CH), 7.03 (d, 1H, CH-CH-C-F), $6.50\left(\mathrm{~s}, 1 \mathrm{H}, \mathrm{CH}\right.$ pyrrolic), 3.86-3.78 (set, $\left.1 \mathrm{H}, \mathrm{CH}_{3}-\mathrm{CH}_{-} \mathrm{CH}_{3}\right), 3.21$ (s, $\left.2 \mathrm{H}, \mathrm{C}-\mathrm{CH}_{2}-\mathrm{CO}\right), 3.14\left(\mathrm{~s}, 3 \mathrm{H}, \mathrm{CH}_{3}-\mathrm{SO}_{2}\right), 2.02\left(\mathrm{~s}, 3 \mathrm{H}, \mathrm{CH}_{3}\right.$ pyrrolic), $1.06\left(\mathrm{~d}, 6 \mathrm{H}, \mathrm{CH}-\mathrm{CH}_{3}\right) .{ }^{13} \mathrm{C}$ NMR $\left(100 \mathrm{MHz}, \mathrm{DMSO}-d_{6}\right) \delta(\mathrm{ppm})$ : $171.8(\mathrm{CH}-\mathrm{CO}-\mathrm{NH}), 159.9(\mathrm{C}-\mathrm{F}), 144.2(\mathrm{CH}-\mathrm{C}-\mathrm{CH}), 143.0(\mathrm{~N}-\mathrm{C}-$ $\mathrm{CH}), 140.4(\mathrm{~S}-\mathrm{C}), 134.4(\mathrm{~N}-\mathrm{C}-\mathrm{C}), 130.0(\mathrm{CH}-\mathrm{CH}-\mathrm{CH}), 128.3(\mathrm{CH}-$ $\mathrm{C}-\mathrm{S}), 128.0(\mathrm{C}-\mathrm{CH}-\mathrm{CH}), 124.8\left(\mathrm{~N}-\mathrm{C}-\mathrm{CH}_{3}\right), 120.6\left(\mathrm{CH}-\mathrm{C}-\mathrm{CH}_{2}\right)$, 115.8 ( $\mathrm{CH}-\mathrm{CH}-\mathrm{C}-\mathrm{N}$ ), 113.1 ( $\mathrm{CH}$ pyrrolic), 112.3 ( $\mathrm{CH}-\mathrm{CH}-\mathrm{C}-\mathrm{F})$, $106.5(\mathrm{~F}-\mathrm{C}-\mathrm{CH}-\mathrm{C}-\mathrm{N}), 46.7\left(\mathrm{CH}_{3}-\mathrm{SO}_{2}\right), 44.3\left(\mathrm{CH}_{3}-\mathrm{CH}-\mathrm{CH}_{3}\right), 33.5$ $\left(\mathrm{CH}_{2} \mathrm{CO}\right), 23.1\left(\mathrm{CH}_{3}-\mathrm{CH}\right), 9.7\left(\mathrm{CH}_{3}\right.$ pyrrolic). MS-ESI: $\mathrm{m} / z 451.15$ $[\mathrm{M}+\mathrm{Na}]^{+}$.

4.1.1.4. 2-(1-(4-Fluorophenyl)-2-methyl-5-(4-(methylsulfonyl) phenyl)-1H-pyrrol-3-yl)- $\boldsymbol{N}$-isopropylacetamide (4). White powder, mp $178{ }^{\circ} \mathrm{C}$ (yield 80\%). ${ }^{1} \mathrm{H}$ NMR (400 MHz, DMSO-d $\left.d_{6}\right) \delta$ ppm: 7.76 (t, 1H, NH), 7.68 (d, 2H, $-\mathrm{C}-\mathrm{CH}-\mathrm{CH}), 7.30-7.28(\mathrm{~m}, 4 \mathrm{H}$, $\mathrm{H}$ aromatic), 7.17 (d, 2H, S-C-CH-CH), 6.49 (s, 1H, CH pyrrolic), 3.85-3.79 (sest, $1 \mathrm{H}, \mathrm{CH}_{3}-\mathrm{CH}-\mathrm{CH}_{3}$ ), 3.20 (s, $2 \mathrm{H}, \mathrm{C}-\mathrm{CH}_{2}-\mathrm{CO}$ ), 3.13 (s, 3H, $\mathrm{CH}_{3}-\mathrm{SO}_{2}$ ), 1.98 (s, 3H, $\mathrm{CH}_{3}$ pyrrolic), 1.05 (d, 6H, $\left.\mathrm{CH}-\mathrm{CH}_{3}\right)$. ${ }^{13} \mathrm{C}$ NMR $\left(100 \mathrm{MHz}, \mathrm{DMSO}-d_{6}\right) \delta(\mathrm{ppm}): 171.9(\mathrm{CH}-\mathrm{CO}-\mathrm{NH})$, $160.0(\mathrm{C}-\mathrm{F}), 147.3(\mathrm{CH}-\mathrm{C}-\mathrm{N}), 145.1(\mathrm{CH}-\mathrm{C}-\mathrm{CH}), 141.5(\mathrm{~S}-\mathrm{C})$, $135.2(\mathrm{~N}-\mathrm{C}-\mathrm{C}), 129.3(\mathrm{CH}-\mathrm{C}-\mathrm{S}), 128.5(\mathrm{C}-\mathrm{CH}-\mathrm{CH}), 126.3(\mathrm{~N}-\mathrm{C}-$ $\left.\mathrm{CH}_{3}\right), 122.29(\mathrm{CH}-\mathrm{CH}-\mathrm{C}-\mathrm{N}), 121.3\left(\mathrm{CH}-\mathrm{C}-\mathrm{CH}_{2}\right), 116.9(\mathrm{CH}-\mathrm{CH}-$ $\mathrm{C}-\mathrm{F}), 114.3$ ( $\mathrm{CH}$ pyrrolic), $48.2\left(\mathrm{CH}_{3}-\mathrm{SO}_{2}\right), 44.0\left(\mathrm{CH}_{3}-\mathrm{CH}-\mathrm{CH}_{3}\right)$, $35.1\left(\mathrm{CH}_{2} \mathrm{CO}\right), 23.5\left(\mathrm{CH}_{3}-\mathrm{CH}\right), 10.2\left(\mathrm{CH}_{3}\right.$ pyrrolic). MS-ESI: $\mathrm{m} / z$ $451.15[\mathrm{M}+\mathrm{Na}]^{+}$.

\subsubsection{General procedure for preparation of 2-methyl-5-(4-((2- (trimethylsilyl) ethyl)sulfonyl) phenyl)-1H-pyrroles 15a,b}

A butyllithium solution ( $3.38 \mathrm{mmol}, 1.38 \mathrm{~mL}, 2.5 \mathrm{M}$ in hexane) was slowly added to a mixture of DIPA $(4.03 \mathrm{mmol}, 0.58 \mathrm{~mL})$ in dry THF $(10 \mathrm{~mL})$, at $0{ }^{\circ} \mathrm{C}$ and under nitrogen flow. The reaction mixture was stirred for thirty minutes and was cooled down to $-78{ }^{\circ} \mathrm{C}$, then a solution of the suitable pyrrole $(\mathbf{1 4 a}, \mathbf{b})$ $(2.9 \mathrm{mmol})$ in dry THF $(10 \mathrm{~mL})$ was added dropwise. After $1,5-$ h stirring, iodomethyltrimethylsilane $(4.03 \mathrm{mmol}, 0.61 \mathrm{~mL})$ was added and the mixture was allowed to warm up to room temperature and to stir for $15 \mathrm{~h}$. The reaction mixture was quenched with water and the $\mathrm{pH}$ was adjusted $(\mathrm{pH}=2)$ with $1 \mathrm{~N} \mathrm{HCl}$. The resulting mixture was extracted with ethyl acetate and the organic layers were washed with brine and dried over $\mathrm{Na}_{2} \mathrm{SO}_{4}$. After concentration in vacuo the crude products were purified by chromatography on silica gel using cyclohexane/ethylacetate $15: 1(\mathrm{v} / \mathrm{v})$ as eluent to give the expected products $\mathbf{1 5} \mathbf{a}, \mathbf{b}$ as white powder.
4.1.2.1. 1-(3-Fluorophenyl)-2-methyl-5-(4-((2-(trimethylsilyl) ethyl) sulfonyl)phenyl)-1H-pyrrole (15a). White powder, mp $78{ }^{\circ} \mathrm{C}$ (60\% yield). ${ }^{1} \mathrm{H}$ NMR (400 MHz, $\left.\mathrm{CDCl}_{3}\right) \delta(\mathrm{ppm}): 7.66$ (d, 2H, $-\mathrm{C}-\mathrm{CH}-\mathrm{CH}$ ), 7.40-7.36 (m, 1H, CH-CH-CH), 7.20 (d, 2H, S-C$\mathrm{CH}-\mathrm{CH}), 7.14-7.09(\mathrm{~m}, 1 \mathrm{H}, \mathrm{N}-\mathrm{C}-\mathrm{CH}-\mathrm{C}-\mathrm{F}), 6.97-6.95(\mathrm{~m}, 1 \mathrm{H}, \mathrm{C}-$ $\mathrm{CH}-\mathrm{CH}), 6.91-6.89$ ( $\mathrm{m}, 1 \mathrm{H}, \mathrm{CH}-\mathrm{CH}-\mathrm{C}-\mathrm{F}), 6.52$ (d, $1 \mathrm{H}, \mathrm{CH}$ pyrrolic), $6.14\left(\mathrm{~d}, 1 \mathrm{H}, \mathrm{CH}\right.$ pyrrolic), $2.98-2.93\left(\mathrm{~m}, 2 \mathrm{H}, \mathrm{CH}_{2}-\mathrm{CH}_{2}-\mathrm{SO}_{2}\right), 2.18(\mathrm{~s}$, $3 \mathrm{H}, \mathrm{CH}_{3}$ pyrrolic), $0.92-0.88\left(\mathrm{~m}, 2 \mathrm{H}, \mathrm{Si}-\mathrm{CH}_{2}-\mathrm{CH}_{2}\right), 0.03(\mathrm{~s}, 9 \mathrm{H}, \mathrm{Si}-$ $\left.\mathrm{CH}_{3}\right) .{ }^{13} \mathrm{C}$ NMR $\left(100 \mathrm{MHz}, \mathrm{CDCl}_{3}\right): \delta(\mathrm{ppm}) 163.2(\mathrm{C}-\mathrm{F}), 144.8$ (CH-C-CH), $142.9(\mathrm{~N}-\mathrm{C}-\mathrm{CH}), 139.3(\mathrm{~S}-\mathrm{C}), 133.2(\mathrm{~N}-\mathrm{C}-\mathrm{C}), 131.5$ $(\mathrm{CH}-\mathrm{CH}-\mathrm{CH}), 129.1(\mathrm{CH}-\mathrm{C}-\mathrm{S}), 128.7\left(\mathrm{~N}-\mathrm{C}_{-} \mathrm{CH}_{3}\right), 128.3(\mathrm{C}-\mathrm{CH}-$ $\mathrm{CH}), 117.5(\mathrm{~N}-\mathrm{C}-\mathrm{CH}-\mathrm{CH}), 112.6(\mathrm{C}-\mathrm{CH}-\mathrm{CH}$ pyrrolic $), 112.1(\mathrm{CH}-$ $\mathrm{CH}-\mathrm{C}-\mathrm{F}), 110.3$ ( $\mathrm{CH}-\mathrm{CH}-\mathrm{C}-\mathrm{CH}_{3}$ pyrrolic), 108.6 (F-C-CH-C-N), $58.4\left(\mathrm{SO}_{2}-\mathrm{CH}_{2}\right), 15.3\left(\mathrm{CH}_{2}-\mathrm{CH}_{2}-\mathrm{Si}\right), 13.2\left(\mathrm{CH}_{3}\right.$ pyrrolic), 2.1 ( $\mathrm{Si}-$ $\mathrm{CH}_{3}$ ). MS-ESI: $m / z 438.13[\mathrm{M}+\mathrm{Na}]^{+}$.

4.1.2.2. 1-(4-Fluorophenyl)-2-methyl-5-(4-((2-(trimethylsilyl)ethyl) sulfonyl)phenyl)-1H-pyrrole (15b). White powder, mp $75{ }^{\circ} \mathrm{C}\left(60 \%\right.$ yield). ${ }^{1} \mathrm{H}$ NMR (400 MHz, $\left.\mathrm{CDCl}_{3}\right) \delta$ (ppm): 7.63 (d, $2 \mathrm{H}$, -C-CH-CH), 7.15-7.08 ( $\mathrm{m}, 6 \mathrm{H}, \mathrm{H}$ aromatic), 6.51 (d, $1 \mathrm{H}, \mathrm{CH}$ pyrrolic), $6.13\left(\mathrm{~d}, 1 \mathrm{H}, \mathrm{CH}\right.$ pyrrolic), 2.98-2.93 (m, $2 \mathrm{H}, \mathrm{CH}_{2}-\mathrm{CH}_{2}-\mathrm{SO}_{2}$ ), 2.13 (s, $3 \mathrm{H}, \mathrm{CH}_{3}$ pyrrolic), $0.93-0.86\left(\mathrm{~m}, 2 \mathrm{H}, \mathrm{Si}-\mathrm{CH}_{2}-\mathrm{CH}_{2}\right), 0.03(\mathrm{~s}, 9 \mathrm{H}$, $\left.\mathrm{Si}-\mathrm{CH}_{3}\right) .{ }^{13} \mathrm{C}$ NMR $\left(100 \mathrm{MHz}, \mathrm{CDCl}_{3}\right) \delta(\mathrm{ppm}): 160.1(\mathrm{C}-\mathrm{F}), 146.3$ $(\mathrm{N}-\mathrm{C}-\mathrm{CH}), 142.8(\mathrm{CH}-\mathrm{C}-\mathrm{CH}), 139.3(\mathrm{~S}-\mathrm{C}), 133.2(\mathrm{~N}-\mathrm{C}-\mathrm{C}), 128.6$ (CH-CH-C-S), $128.3\left(\mathrm{~N}-\mathrm{C}-\mathrm{CH}_{3}\right), 127.9(\mathrm{C}-\mathrm{CH}-\mathrm{CH}), 122.4(\mathrm{~N}-\mathrm{C}-$ $\mathrm{CH}-\mathrm{CH}$ ), 117.9 (CH-CH-C-F), 113.1 (C-CH-CH pyrrolic), 110.2 (CH-CH-C-CH $\mathrm{CH}_{3}$ pyrrolic), $58.2\left(\mathrm{SO}_{2}-\mathrm{CH}_{2}\right), 15.4\left(\mathrm{CH}_{2}-\mathrm{CH}_{2}-\mathrm{Si}\right), 13.3$ $\left(\mathrm{CH}_{3}\right.$ pyrrolic), $2.1\left(\mathrm{Si}-\mathrm{CH}_{3}\right)$. MS-ESI: $m / z 438.13[\mathrm{M}+\mathrm{Na}]^{+}$.

\subsubsection{General procedure for the preparation of sulfonamide pyrroles 16a,b}

A solution of tetrabutylammonium fluoride in hexane (3,6 mmol, $3.6 \mathrm{~mL})$ was added to the appropriate trimethylsilylpyrrole $\mathbf{1 5 a}, \mathbf{b}(1.2 \mathrm{mmol})$ and was microwave irradiated at $120^{\circ} \mathrm{C}$ for $15 \mathrm{~min}$ (power $150 \mathrm{~W}$, pressure $170 \mathrm{psi}$ ). A solution of sodium acetate $(3,6 \mathrm{mmol}, 0.29 \mathrm{~g})$ in water $(3.6 \mathrm{~mL})$ and hydroxylamine- $O$ sulfonic acid ( $3.6 \mathrm{mmol}, 0.41 \mathrm{~g}$ ) was then added; the mixture was irradiated again for $10 \mathrm{~min}$ at $50{ }^{\circ} \mathrm{C}$ (power $150 \mathrm{~W}$, pressure $170 \mathrm{psi}$ ). The reaction mixture was then quenched with water, extracted with ethyl acetate and then washed with brine. The organic layers were dried over $\mathrm{Na}_{2} \mathrm{SO}_{4}$, filtered off and concentrated in vacuo. The obtained crude products were purified by chromatography on silica gel using petroleum ether/ethylacetate $2: 1(\mathrm{v} / \mathrm{v})$ as eluent. After recrystallization from diethyl ether the expected products $\mathbf{1 6 a}, \mathbf{b}$ were obtained.

4.1.3.1. 4-(1-(3-Fluorophenyl)-5-methyl-1H-pyrrol-2-yl) benzenesulfonamide (16a). White powder, mp $115{ }^{\circ} \mathrm{C}(80 \%$ yield). ${ }^{1} \mathrm{H}$ NMR (400 MHz, $\left.\mathrm{CDCl}_{3}\right) \delta(\mathrm{ppm}): 7.67$ (d, $2 \mathrm{H},-\mathrm{C}-\mathrm{CH}-$ $\mathrm{CH}), 7.46-7.42(\mathrm{~m}, 1 \mathrm{H}, \mathrm{CH}-\mathrm{CH}-\mathrm{CH}), 7.28-7.26(\mathrm{~m}, 1 \mathrm{H}, \mathrm{C}-\mathrm{CH}-\mathrm{CH})$, 7.07-7.03 (m, 1H, N-C-CH-C-F), 6.94-6.91 (m, 2H, S-C-CH-CH), 6.89-6.86 (m, 1H, CH-CH-C-F), 6.48 (d, 1H, CH pyrrolic), 6.15 (d, $1 \mathrm{H}, \mathrm{CH}$ pyrrolic), 4.81 (s, broad, $\left.2 \mathrm{H}, \mathrm{NH}_{2}\right), 2.14$ (s, $3 \mathrm{H}, \mathrm{CH}_{3}$ pyrrolic). ${ }^{13} \mathrm{C}$ NMR $\left(100 \mathrm{MHz}, \mathrm{CDCl}_{3}\right) \delta(\mathrm{ppm}): 163.3(\mathrm{C}-\mathrm{F}), 145.6(\mathrm{~S}-\mathrm{C}), 143.1$ $(\mathrm{N}-\mathrm{C}-\mathrm{CH}), 141.9(\mathrm{CH}-\mathrm{C}-\mathrm{CH}), 134.3(\mathrm{~N}-\mathrm{C}-\mathrm{C}), 131.6(\mathrm{CH}-\mathrm{CH}-\mathrm{CH})$, $129.1\left(\mathrm{~N}-\mathrm{C}-\mathrm{CH}_{3}\right), 128.3(\mathrm{CH}-\mathrm{C}-\mathrm{S}), 126.9(\mathrm{C}-\mathrm{CH}-\mathrm{CH}), 116.9(\mathrm{~N}-\mathrm{C}-$ $\mathrm{CH}-\mathrm{CH}), 113.2$ (C-CH-CH pyrrolic), 112.9 (CH-CH-C-F), 110.4 ( $\mathrm{CH}-\mathrm{CH}-\mathrm{C}-\mathrm{CH}_{3}$ pyrrolic), 108.1 (F-C-CH-C-N), $12.6\left(\mathrm{CH}_{3}\right.$ pyrrolic). MS-ESI: $m / z$ 353.07 [M+Na $]^{+}$.

4.1.3.2. 4-(1-(4-Fluorophenyl)-5-methyl-1H-pyrrol-2-yl) benzenesulfonamide (16b). White powder, $\mathrm{mp} 126{ }^{\circ} \mathrm{C}(80 \%$ yield $)$. ${ }^{1} \mathrm{H}$ NMR $\left(400 \mathrm{MHz}, \mathrm{CDCl}_{3}\right) \delta(\mathrm{ppm}): 7.67$ (d, 2H, $\left.-\mathrm{C}-\mathrm{CH}-\mathrm{CH}\right), 7.13-$ 7.09 (m, $6 \mathrm{H}, \mathrm{H}$ aromatic), 6.48 (d, $1 \mathrm{H}, \mathrm{CH}$ pyrrolic), 6.13 (d, $1 \mathrm{H}, \mathrm{CH}$ pyrrolic), 4.71 (s broad, $2 \mathrm{H}, \mathrm{NH}_{2}$ ), 2.13 (s, 3H, $\mathrm{CH}_{3}$ pyrrolic). ${ }^{13} \mathrm{C}$ NMR $\left(100 \mathrm{MHz}, \mathrm{CDCl}_{3}\right) \delta(\mathrm{ppm}): 163.8(\mathrm{C}-\mathrm{F}), 146.1(\mathrm{~N}-\mathrm{C}-\mathrm{CH})$, 
144.1 (S-C), $141.5(\mathrm{CH}-\mathrm{C}-\mathrm{CH}), 133.3(\mathrm{~N}-\mathrm{C}-\mathrm{C}), 130.8\left(\mathrm{~N}-\mathrm{C}-\mathrm{CH}_{3}\right)$, 129.1 (CH-CH-C-S), $128.8(\mathrm{C}-\mathrm{CH}-\mathrm{CH}), 121.4(\mathrm{~N}-\mathrm{C}-\mathrm{CH}-\mathrm{CH})$, 116.9 ( $\mathrm{CH}-\mathrm{CH}-\mathrm{C}-\mathrm{F}$ ), 114.2 (C-CH-CH pyrrolic), 108.8 (CH-CH-C$\mathrm{CH}_{3}$ pyrrolic), 12.8 ( $\mathrm{CH}_{3}$ pyrrolic). MS-ESI: $m / z 353.07[\mathrm{M}+\mathrm{Na}]^{+}$.

\subsubsection{General procedure for the preparation of 1,5 -diarylpyrrol-} 3-glyoxylic esters 17a,b

Ethoxalyl chloride $(3.0 \mathrm{mmol})$ and $\mathrm{TiCl}_{4}(3.0 \mathrm{mmol})$ were added in sequence, at $0{ }^{\circ} \mathrm{C}$ and under nitrogen atmosphere, to a solution of the appropriate pyrrole $(\mathbf{1 6 a}, \mathbf{b})(3.0 \mathrm{mmol})$ in dry dichloromethane $(10 \mathrm{~mL})$. The resulting solution was allowed to warm up to room temperature and stirred for $4 \mathrm{~h}$. The mixture was then diluted with water and the two phases were separated with dichloromethane. The organic layers were washed with brine, dried over $\mathrm{Na}_{2} \mathrm{SO}_{4}$, and evaporated in vacuo, then the crude material was purified by chromatography on silica gel employing petroleum ether/ethyl acetate, 3:1 (v/v) as eluent. After recrystallization from diethyl ether the expected products 17a,b were obtained.

4.1.4.1. Ethyl-2-(1-(3-fluorophenyl)-2-methyl-5-(4-sulfamoylphenyl)-1H-pyrrol-3-yl)-2-oxoacetate (17a). White powder, mp $175{ }^{\circ} \mathrm{C}$, (60\% yield). ${ }^{1} \mathrm{H}$ NMR $\left(400 \mathrm{MHz}, \mathrm{CDCl}_{3}\right) \delta$ ppm: 7.75 (d, 2H, $-\mathrm{C}-\mathrm{CH}-\mathrm{CH}), 7.45-7.43(\mathrm{~m}, 1 \mathrm{H}, \mathrm{CH}-\mathrm{CH}-\mathrm{CH}), 7.20-7.19(\mathrm{~m}$, $1 \mathrm{H}, \mathrm{N}-\mathrm{C}-\mathrm{CH}-\mathrm{C}-\mathrm{F}), 7.17$ (d, 2H, S-C-CH-CH), 7.07 (s, 1H, CH pyrrolic), $6.97(\mathrm{~d}, 1 \mathrm{H}, \mathrm{C}-\mathrm{CH}-\mathrm{CH}), 6.89(\mathrm{~m}, 1 \mathrm{H}, \mathrm{CH}-\mathrm{CH}-\mathrm{C}-\mathrm{F}), 4.75(\mathrm{~s}$ broad, $2 \mathrm{H}, \mathrm{NH}_{2}$ ), 4.42 (q, $\left.2 \mathrm{H}, \mathrm{OCH}_{2}-\mathrm{CH}_{3}\right), 2.47$ (s, 3H, $\mathrm{CH}_{3}$ pyrrolic), $1.43\left(\mathrm{t}, 3 \mathrm{H}, \mathrm{CH}_{2} \mathrm{CH}_{3}\right) .{ }^{13} \mathrm{C}$ NMR $\left(100 \mathrm{MHz}, \mathrm{CDCl}_{3}\right) \delta(\mathrm{ppm}): 183.2$ (CH-CO), 166.2 (CO-O), $162.9(\mathrm{C}-\mathrm{F}), 145.8(\mathrm{~S}-\mathrm{C}), 144.2(\mathrm{~N}-\mathrm{C}-\mathrm{CH})$, $142.3(\mathrm{CH}-\mathrm{C}-\mathrm{CH}), 135.2\left(\mathrm{~N}-\mathrm{C}-\mathrm{CH}_{3}\right), 133.4(\mathrm{~N}-\mathrm{C}-\mathrm{C}), 131.4(\mathrm{CH}-$ $\mathrm{CH}-\mathrm{CH}), 129.3(\mathrm{CH}-\mathrm{C}-\mathrm{S}), 128.6(\mathrm{C}-\mathrm{CH}-\mathrm{CH}), 117.1(\mathrm{~N}-\mathrm{C}-\mathrm{CH}-\mathrm{CH})$, 113.7 ( $\mathrm{CH}-\mathrm{CH}-\mathrm{C}-\mathrm{F}), 112.1$ (C-CO pyrrolic), 107.2 ( $\mathrm{CH}$ pyrrolic), $106.8(\mathrm{~F}-\mathrm{C}-\mathrm{CH}-\mathrm{C}-\mathrm{N}), 61.7\left(\mathrm{O}-\mathrm{CH}_{2} \mathrm{CH}_{3}\right), 13.6\left(\mathrm{CH}_{2}-\mathrm{CH}_{3}\right), 12.8$ $\left(\mathrm{CH}_{3}\right.$ pyrrolic). MS-ESI: $\mathrm{m} / z 453.09[\mathrm{M}+\mathrm{Na}]^{+}$.

4.1.4.2. Ethyl-2-(1-(4-fluorophenyl)-2-methyl-5-(4-sulfamoylphenyl)-1H-pyrrol-3-yl)-2-oxoacetate (17b). White powder, mp $177^{\circ} \mathrm{C}(60 \%$ yield $) .{ }^{1} \mathrm{H}$ NMR $\left(400 \mathrm{MHz}, \mathrm{CDCl}_{3}\right) \delta$ ppm: $7.72(\mathrm{~d}$, $2 \mathrm{H},-\mathrm{C}-\mathrm{CH}-\mathrm{CH}$ ), 7.16-7.13 (m, 6H, $\mathrm{H}$ aromatic), 7.05 (s, $1 \mathrm{H}, \mathrm{CH}$ pyrrolic), 4.72 (s broad, $\left.2 \mathrm{H}, \mathrm{NH}_{2}\right), 4.41\left(\mathrm{q}, 2 \mathrm{H}, \mathrm{OCH}_{2}-\mathrm{CH}_{3}\right), 2.44(\mathrm{~s}, 3 \mathrm{H}$, $\mathrm{CH}_{3}$ pyrrolic), $1.42\left(\mathrm{t}, 3 \mathrm{H}, \mathrm{CH}_{2} \mathrm{CH}_{3}\right) .{ }^{13} \mathrm{C}$ NMR $\left(100 \mathrm{MHz}, \mathrm{CDCl}_{3}\right) \delta$ (ppm): 183.0 (CH-CO), 166.4 (CO-O), 162.9 (C-F), $146.4(\mathrm{~S}-\mathrm{C})$, $143.8(\mathrm{~N}-\mathrm{C}-\mathrm{CH}), 142.3(\mathrm{CH}-\mathrm{C}-\mathrm{CH}), 134.9\left(\mathrm{~N}-\mathrm{C}_{-} \mathrm{CH}_{3}\right), 131.4(\mathrm{~N}-$ C-C), 128.2 ( $\mathrm{CH}-\mathrm{C}-\mathrm{S}), 127.5(\mathrm{C}-\mathrm{CH}-\mathrm{CH}), 121.3(\mathrm{~N}-\mathrm{C}-\mathrm{CH}-\mathrm{CH})$, 117.6 ( $\mathrm{CH}-\mathrm{CH}-\mathrm{C}-\mathrm{F}$ ), 112.8 ( $\mathrm{C}-\mathrm{CO}$ pyrrolic), 106.5 ( $\mathrm{CH}$ pyrrolic), $62.1\left(\mathrm{O}-\mathrm{CH}_{2} \mathrm{CH}_{3}\right), 13.8\left(\mathrm{CH}_{2}-\mathrm{CH}_{3}\right), 12.7\left(\mathrm{CH}_{3}\right.$ pyrrolic). MS-ESI: $\mathrm{m} /$ z $453.09[\mathrm{M}+\mathrm{Na}]^{+}$.

\subsubsection{General procedure for the preparation of 1,5-diarylpyrrol acetic esters 5 and 6}

To a solution of the appropriate glyoxylic ester $(\mathbf{1 7 a}, \mathbf{b})$ $(2.3 \mathrm{mmol})$ in trifluoroacetic acid $(16.1 \mathrm{~mL})$ at $0{ }^{\circ} \mathrm{C}$ and under nitrogen atmosphere, triethylsilane $(6.9 \mathrm{mmol}, 1.1 \mathrm{~mL})$ was slowly added. The mixture was allowed to warm up to room temperature and stirred for two hours, then was diluted with water and was made alkaline $(\mathrm{pH}=12)$ using a solution of $40 \%$ aqueous ammonia. The mixture was then extracted with dichloromethane, washed with brine, dried over $\mathrm{Na}_{2} \mathrm{SO}_{4}$, filtered, and evaporated in vacuo. The crude products were purified by chromatography on silica gel, using as eluent petroleum ether/ethyl acetate $2: 1(\mathrm{v} / \mathrm{v})$. After recrystallization from diethyl ether, the acetic esters $\mathbf{5}$ and $\mathbf{6}$ were obtained.

4.1.5.1. Ethyl 2-(1-(3-fluorophenyl)-2-methyl-5-(4-sulfamoylphenyl)-1H-pyrrol-3-yl)acetate (5). White powder, mp $164{ }^{\circ} \mathrm{C}$ (65\% yield). ${ }^{1} \mathrm{H}$ NMR $\left(400 \mathrm{MHz}, \mathrm{CDCl}_{3}\right) \delta \mathrm{ppm}: 7.66(\mathrm{~d}, 2 \mathrm{H}$, $-\mathrm{C}-\mathrm{CH}-\mathrm{CH}), 7.38-7.34(\mathrm{~m}, 1 \mathrm{H}, \mathrm{CH}-\mathrm{CH}-\mathrm{CH}), 7.13-7.10(\mathrm{~m}, 1 \mathrm{H}, \mathrm{N}-$ C-CH-C-F), 7.08 (d, 2H, S-C-CH-CH), 6.96 (d, 2H, C-CH-CH),
6.45 (s, $1 \mathrm{H}, \mathrm{CH}$ pyrrolic), 4,86 (s, broad, $\left.2 \mathrm{H}, \mathrm{NH}_{2}\right), 4.08$ (q, $2 \mathrm{H}$, $\left.\mathrm{OCH}_{2}-\mathrm{CH}_{3}\right), 3.48$ (s, $\left.2 \mathrm{H}, \mathrm{C}-\mathrm{CH}_{2}-\mathrm{CO}\right), 2.01$ (s, 3H, $\mathrm{CH}_{3}$ pyrrolic), $1.20\left(\mathrm{t}, 3 \mathrm{H}, \mathrm{CH}_{2} \mathrm{CH}_{3}\right) .{ }^{13} \mathrm{C} \mathrm{NMR}\left(100 \mathrm{MHz}, \mathrm{CDCl}_{3}\right) \delta(\mathrm{ppm}): 169.2$ (CO-O), 163.8 (C-F), 144.8 (S-C), 143.7 (N-C-CH), 142.3 (CH-C$\mathrm{CH}), 134.2(\mathrm{~N}-\mathrm{C}-\mathrm{C}), 131.4(\mathrm{CH}-\mathrm{CH}-\mathrm{CH}), 129.3(\mathrm{CH}-\mathrm{C}-\mathrm{S}), 128.6$ $(\mathrm{C}-\mathrm{CH}-\mathrm{CH}), 125.9\left(\mathrm{~N}-\mathrm{C}-\mathrm{CH}_{3}\right), 122.3\left(\mathrm{C}-\mathrm{CH}_{2}\right), 116.1(\mathrm{~N}-\mathrm{C}-\mathrm{CH}-$ $\mathrm{CH}), 113.5$ ( $\mathrm{CH}$ pyrrolic), $111.9(\mathrm{CH}-\mathrm{CH}-\mathrm{C}-\mathrm{F}), 107.4$ (F-C-CH-C$\mathrm{N}), 61.3\left(\mathrm{O}-\mathrm{CH}_{2} \mathrm{CH}_{3}\right), 34.2\left(\mathrm{CH}_{2}-\mathrm{CO}\right), 13.6\left(\mathrm{CH}_{2}-\mathrm{CH}_{3}\right), 10.8\left(\mathrm{CH}_{3}\right.$ pyrrolic). MS-ESI: $m / z 439.11[\mathrm{M}+\mathrm{Na}]^{+}$.

4.1.5.2. Ethyl 2-(1-(4-fluorophenyl)-2-methyl-5-(4-sulfamoylphenyl)-1H-pyrrol-3-yl)acetate (6). White powder, mp $149{ }^{\circ} \mathrm{C}$ (65\% yield). ${ }^{1} \mathrm{H}$ NMR $\left(400 \mathrm{MHz}, \mathrm{CDCl}_{3}\right) \delta \mathrm{ppm}: 7.67(\mathrm{~d}, 2 \mathrm{H}$, -C-CH-CH), 7.13-7.08 (m, 6H, $\mathrm{H}$ aromatic), 6.50 (s, $1 \mathrm{H}, \mathrm{CH}$ pyrrolic), 4.72 (s broad, $\left.2 \mathrm{H}, \mathrm{NH}_{2}\right), 4.20$ (q, $\left.2 \mathrm{H}, \mathrm{OCH}_{2}-\mathrm{CH}_{3}\right), 3.51$ (s, $2 \mathrm{H}, \mathrm{C}-$ $\mathrm{CH}_{2}-\mathrm{CO}$ ), 2.06 (s, 3H, $\mathrm{CH}_{3}$ pyrrolic), $1.29\left(\mathrm{t}, 3 \mathrm{H}, \mathrm{CH}_{2} \mathrm{CH}_{3}\right) .{ }^{13} \mathrm{C} \mathrm{NMR}$ $\left(100 \mathrm{MHz}, \mathrm{CDCl}_{3}\right) \delta(\mathrm{ppm}): 169.1(\mathrm{CO}-\mathrm{O}), 160.9(\mathrm{C}-\mathrm{F}), 146.8(\mathrm{~N}-\mathrm{C}-$ $\mathrm{CH}), 143.4(\mathrm{~S}-\mathrm{C}), 142.5(\mathrm{CH}-\mathrm{C}-\mathrm{CH}), 134.4(\mathrm{~N}-\mathrm{C}-\mathrm{C}), 128.8(\mathrm{CH}-\mathrm{C}-$ $\mathrm{S}), 127.7(\mathrm{C}-\mathrm{CH}-\mathrm{CH}), 125.6\left(\mathrm{~N}-\mathrm{C}-\mathrm{CH}_{3}\right), 122.3(\mathrm{~N}-\mathrm{C}-\mathrm{CH}-\mathrm{CH})$, 121.4 ( $\mathrm{C}-\mathrm{CH}_{2}$ pyrrolic), 116.2 ( $\left.\mathrm{CH}-\mathrm{CH}-\mathrm{C}-\mathrm{F}\right), 113.3$ ( $\mathrm{CH}$ pyrrolic), $61.4\left(\mathrm{O}-\mathrm{CH}_{2} \mathrm{CH}_{3}\right), 34.5\left(\mathrm{CH}_{2}-\mathrm{CO}\right), 14.6\left(\mathrm{CH}_{2}-\mathrm{CH}_{3}\right), 10.2\left(\mathrm{CH}_{3}\right.$ pyrrolic). MS-ESI: $m / z 439.11[\mathrm{M}+\mathrm{Na}]^{+}$.

\subsubsection{General procedure for the preparation of 1,5-diarylpyrrol acetic acids 7 and 8}

After dissolution of the appropriate acetic ester (5 and $\mathbf{6}$ ) $(1.3 \mathrm{mmol})$ in ethanol $(9.4 \mathrm{~mL})$, a solution of $\mathrm{NaOH}(0.38 \mathrm{~g})$ in water $(9.4 \mathrm{~mL})$ was added dropwise. The mixture was refluxed for two hours and then the residue was solubilized in water ( $5 \mathrm{~mL}$ ) and then concentrated $\mathrm{HCl}$ was added dropwise until a precipitate was formed. The precipitate was filtered off to give the expected acids $\mathbf{7}$ and $\mathbf{8}$ as white solids.

4.1.6.1. 2-(1-(3-Fluorophenyl)-2-methyl-5-(4-sulfamoylphenyl)1H-pyrrol-3-yl)acetic acid (7). White powder, mp $182{ }^{\circ} \mathrm{C}$ (>90\% yield). ${ }^{1} \mathrm{H}$ NMR (400 MHz, DMSO- $\left.d_{6}\right) \delta$ ppm: 12.17 (s broad, $1 \mathrm{H}, \mathrm{COOH}$ ), 7.59 (d, 2H, $-\mathrm{C}-\mathrm{CH}-\mathrm{CH}), 7.28-7.25$ ( $\mathrm{m}, 4 \mathrm{H}, \mathrm{H}$ aromatic), 7.22 (s broad, $2 \mathrm{H}, \mathrm{SO}_{2} \mathrm{NH}_{2}$ ), 7.10 (d, 2H, S-C-CH-CH), 7.04-7.03 (m, $1 \mathrm{H}, \mathrm{CH}-\mathrm{CH}-\mathrm{C}-\mathrm{F}), 6.46$ (s, $1 \mathrm{H}, \mathrm{CH}$ pyrrolic), 3.31 (s, 2H, C-CH $-\mathrm{CO}$ ), $2.01\left(\mathrm{~s}, 2 \mathrm{H}, \mathrm{CH}_{3}\right.$ pyrrolic). ${ }^{13} \mathrm{C}$ NMR $\left(100 \mathrm{MHz}, \mathrm{DMSO}-\mathrm{d}_{6}\right) \delta$ (ppm): 176.3 (CO-O), $163.5(\mathrm{C}-\mathrm{F}), 143.8(\mathrm{~S}-\mathrm{C}), 142.9(\mathrm{~N}-\mathrm{C}-\mathrm{CH}), 142.0(\mathrm{CH}-$ $\mathrm{C}-\mathrm{CH}), 134.2(\mathrm{~N}-\mathrm{C}-\mathrm{C}), 130.6(\mathrm{CH}-\mathrm{CH}-\mathrm{CH}), 128.1(\mathrm{CH}-\mathrm{C}-\mathrm{S}), 127.8$ (C-CH-CH), $125.4\left(\mathrm{~N}-\mathrm{C}-\mathrm{CH}_{3}\right), 121.3\left(\mathrm{C}-\mathrm{CH}_{2}\right), 116.1(\mathrm{~N}-\mathrm{C}-\mathrm{CH}-\mathrm{CH})$, 113.3 (CH pyrrolic), 112.0 (CH-CH-C-F), 107.2 (F-C-CH-C-N), 36.2 $\left(\mathrm{CH}_{2}-\mathrm{CO}\right), 10.2\left(\mathrm{CH}_{3}\right.$ pyrrolic). MS-ESI: $m / z 411.08[\mathrm{M}+\mathrm{Na}]^{+}$.

4.1.6.2. 2-(1-(4-Fluorophenyl)-2-methyl-5-(4-sulfamoylphenyl)1H-pyrrol-3-yl)acetic acid (8). $\quad{ }^{1} \mathrm{H}$ NMR (400 MHz, DMSO- $\left.d_{6}\right)$ $\delta$ ppm: 12.15 (s broad, $1 \mathrm{H}, \mathrm{COOH}$ ), 7.59 (d, 2H, -C-CH-CH), 7.35$7.30\left(\mathrm{~m}, 4 \mathrm{H}, \mathrm{H}\right.$ aromatic), 7.27 (s broad, $\left.2 \mathrm{H}, \mathrm{SO}_{2} \mathrm{NH}_{2}\right), 7.13(\mathrm{~d}, 2 \mathrm{H}$, $\mathrm{S}-\mathrm{C}-\mathrm{CH}-\mathrm{CH}$ ), 6.48 (s, $1 \mathrm{H}, \mathrm{CH}$ pyrrolic), 3.41 (s, 2H, C-CH $-\mathrm{CO}$ ), $2.03\left(\mathrm{~s}, 3 \mathrm{H}, \mathrm{CH}_{3}\right.$ pyrrolic) ${ }^{13} \mathrm{C}$ NMR $\left(100 \mathrm{MHz}, \mathrm{DMSO}-d_{6}\right) \delta(\mathrm{ppm})$ : 176.1 (CO-O), 157.3 (C-F), $146.8(\mathrm{~N}-\mathrm{C}-\mathrm{CH}), 142.4(\mathrm{~S}-\mathrm{C}), 142.0$ (CH-C-CH), $134.1(\mathrm{~N}-\mathrm{C}-\mathrm{C}), 127.8(\mathrm{CH}-\mathrm{C}-\mathrm{S}), 126.4(\mathrm{C}-\mathrm{CH}-\mathrm{CH})$, $125.0\left(\mathrm{~N}-\mathrm{C}-\mathrm{CH}_{3}\right), 121.3(\mathrm{~N}-\mathrm{C}-\mathrm{CH}-\mathrm{CH}), 119.3\left(\mathrm{C}-\mathrm{CH}_{2}\right.$ pyrrolic $)$, 116.1 (CH-CH-C-F), 113.3 ( $\mathrm{CH}$ pyrrolic), $35.8\left(\mathrm{CH}_{2}-\mathrm{CO}\right), 10.1$ $\left(\mathrm{CH}_{3}\right.$ pyrrolic). MS-ESI: $\mathrm{m} / z 411.08[\mathrm{M}+\mathrm{Na}]^{+}$

\subsubsection{General procedure for the preparation of 4-sulfamoylphenyl acetamides 9-12}

To a solution of the suitable acetic acid (7 and 8$)(0.51 \mathrm{mmol})$ in a mixture of dichloromethane/DCM 10:1 (v/v) under nitrogen flow, the appropriate amine $(2.04 \mathrm{mmol})$, DMAP $(0.61 \mathrm{mmol}, 0.07 \mathrm{~g})$ and EDCI $(0.82 \mathrm{mmol}, 0.16 \mathrm{~g})$ were added in sequence. The reaction mixture was stirred at room temperature for $15 \mathrm{~h}$ and then it 
was diluted with water, and the two phases were separated with dichloromethane. The organic layers were washed with $2 \mathrm{~N} \mathrm{HCl}$, $\mathrm{NaHCO}_{3}$ saturated solution and brine, then was dried $\mathrm{Na}_{2} \mathrm{SO}_{4}$, filtered and concentrated in vacuo. The obtained crude products were purified by column chromatography on silica gel using cyclohexane/ethyl acetate $1: 1$, as eluent. After recrystallization from ethyl acetate, the desired products 9-12 were obtained.

\subsubsection{2-(1-(3-Fluorophenyl)-2-methyl-5-(4-sulfamoylphenyl)-} 1H-pyrrol-3-yl)- $\mathbf{N}$-propylacetamide (9). White powder, mp $192{ }^{\circ} \mathrm{C}$ (yield 60\%). ${ }^{1} \mathrm{H}$ NMR $\left(400 \mathrm{MHz}\right.$, DMSO- $\left.d_{6}\right) \delta$ ppm: $7.85(\mathrm{t}$, $1 \mathrm{H}, \mathrm{NH}), 7.57$ (d, 2H, $-\mathrm{C}-\mathrm{CH}-\mathrm{CH}), 7.50-7.45(\mathrm{~m}, 1 \mathrm{H}, \mathrm{CH}-\mathrm{CH}-\mathrm{CH})$, 7.31-7.29 (m, 1H, N-C-CH-CH),7.24 (s broad, $2 \mathrm{H}, \mathrm{SO}_{2} \mathrm{NH}_{2}$ ), 7.20$7.17(\mathrm{~m}, 1 \mathrm{H}, \mathrm{N}-\mathrm{C}-\mathrm{CH}-\mathrm{C}-\mathrm{F}), 7.12$ (d, 2H, S-C-CH-CH), 7.02 (d, $1 \mathrm{H}$, $\mathrm{CH}-\mathrm{CH}-\mathrm{C}-\mathrm{F}), 6.44\left(\mathrm{~s}, 1 \mathrm{H}, \mathrm{CH}\right.$ pyrrolic), $3.23\left(\mathrm{~s}, 2 \mathrm{H}, \mathrm{C}-\mathrm{CH}_{2}-\mathrm{CO}\right)$, $3.01\left(\mathrm{~m}, 2 \mathrm{H}, \mathrm{N}-\mathrm{CH}_{2}-\mathrm{CH}_{2}\right), 2.02\left(\mathrm{~s}, 3 \mathrm{H}, \mathrm{CH}_{3}\right.$ pyrrolic), 1.44 (sest, $\left.2 \mathrm{H}, \mathrm{CH}_{2}-\mathrm{CH}_{2}-\mathrm{CH}_{3}\right), 0.84\left(\mathrm{t}, 3 \mathrm{H}, \mathrm{CH}_{2}-\mathrm{CH}_{3}\right) .{ }^{13} \mathrm{C} \mathrm{NMR}(100 \mathrm{MHz}$, DMSO-d $\left.d_{6}\right) \delta(\mathrm{ppm}): 171.8(\mathrm{CO}-\mathrm{O}), 164.8(\mathrm{C}-\mathrm{F}), 144.2(\mathrm{~S}-\mathrm{C}), 143.8$ $(\mathrm{N}-\mathrm{C}-\mathrm{CH}), 143.1(\mathrm{CH}-\mathrm{C}-\mathrm{CH}), 134.9(\mathrm{~N}-\mathrm{C}-\mathrm{C}), 131.2(\mathrm{CH}-\mathrm{CH}-\mathrm{CH})$, $127.9(\mathrm{CH}-\mathrm{C}-\mathrm{S}), 127.6(\mathrm{C}-\mathrm{CH}-\mathrm{CH}), 126.4\left(\mathrm{~N}-\mathrm{C}_{-} \mathrm{CH}_{3}\right), 121.8(\mathrm{C}-$ $\left.\mathrm{CH}_{2}\right), 117.5(\mathrm{~N}-\mathrm{C}-\mathrm{CH}-\mathrm{CH}), 113.8$ ( $\mathrm{CH}$ pyrrolic), 112.7 ( $\mathrm{CH}-\mathrm{CH}-\mathrm{C}-$ F), $108.0(\mathrm{~F}-\mathrm{C}-\mathrm{CH}-\mathrm{C}-\mathrm{N}), 43.3\left(\mathrm{NH}-\mathrm{CH}_{2}-\mathrm{CH}_{2}\right), 34.6\left(\mathrm{CH}_{2}-\mathrm{CO}\right)$, $23.5\left(\mathrm{CH}_{2}-\mathrm{CH}_{2}-\mathrm{CH}_{3}\right), 11.8\left(\mathrm{CH}_{2}-\mathrm{CH}_{3}\right), 10.2\left(\mathrm{CH}_{3}\right.$ pyrrolic). MS-ESI: $\mathrm{m} / \mathrm{z} 452.14[\mathrm{M}+\mathrm{Na}]^{+}$.

\subsubsection{2-(1-(4-Fluorophenyl)-2-methyl-5-(4-sulfamoylphenyl)-} 1H-pyrrol-3-yl)- $\mathbf{N}$-propylacetamide (10). White powder, mp $183^{\circ} \mathrm{C}$ (yield 60\%). ${ }^{1} \mathrm{H}$ NMR $\left(400 \mathrm{MHz}\right.$, DMSO- $\left.d_{6}\right) \delta$ ppm: $7.86(\mathrm{t}$, $1 \mathrm{H}, \mathrm{t}, 1 \mathrm{H}, \mathrm{NH}), 7.58$ (d, 2H, $-\mathrm{C}-\mathrm{CH}-\mathrm{CH}), 7.31-7.25$ (m, 4H, $H$ aromatic), 7.24 (s broad, $2 \mathrm{H}, \mathrm{SO}_{2} \mathrm{NH}_{2}$ ), 7.11 (d, $2 \mathrm{H}, \mathrm{S}-\mathrm{C}-\mathrm{CH}-\mathrm{CH}$ ), 6.44 (s, $1 \mathrm{H}, \mathrm{CH}$ pyrrolic), 3.24 (s, 2H, C- $\left.\mathrm{CH}_{2}-\mathrm{CO}\right), 3.02(\mathrm{~m} .2 \mathrm{H}, \mathrm{N}-$ $\mathrm{CH}_{2}-\mathrm{CH}_{2}$ ), 2.00 (s, 3H, $\mathrm{CH}_{3}$ pyrrolic), 1.43 (sest, $2 \mathrm{H}, \mathrm{CH}_{2}-\mathrm{CH}_{2}-$ $\left.\mathrm{CH}_{3}\right), 0.85\left(\mathrm{t}, 3 \mathrm{H}, \mathrm{CH}_{2}-\mathrm{CH}_{3}\right) .{ }^{13} \mathrm{C}$ NMR $\left(100 \mathrm{MHz}\right.$, DMSO- $\left.d_{6}\right) \delta$ (ppm): 171.2 (CO-O), $159.3(\mathrm{C}-\mathrm{F}), 146.6(\mathrm{~N}-\mathrm{C}-\mathrm{CH}), 143.3(\mathrm{~S}-\mathrm{C})$, $142.0(\mathrm{CH}-\mathrm{C}-\mathrm{CH}), 133.9(\mathrm{~N}-\mathrm{C}-\mathrm{C}), 129.2(\mathrm{CH}-\mathrm{C}-\mathrm{S}), 128.0(\mathrm{C}-\mathrm{CH}-$ $\mathrm{CH}), 125.8\left(\mathrm{~N}-\mathrm{C}-\mathrm{CH}_{3}\right), 121.8(\mathrm{~N}-\mathrm{C}-\mathrm{CH}-\mathrm{CH}), 121.0\left(\mathrm{C}-\mathrm{CH}_{2}\right.$ pyrrolic $)$, 115.8 ( $\mathrm{CH}-\mathrm{CH}-\mathrm{C}-\mathrm{F}), 112.6$ ( $\mathrm{CH}$ pyrrolic), $42.5\left(\mathrm{NH}-\mathrm{CH}_{2}-\mathrm{CH}_{2}\right), 33.8$ $\left(\mathrm{CH}_{2}-\mathrm{CO}\right), 23.0\left(\mathrm{CH}_{2}-\mathrm{CH}_{2}-\mathrm{CH}_{3}\right), 11.0\left(\mathrm{CH}_{2}-\mathrm{CH}_{3}\right), 9.8\left(\mathrm{CH}_{3}\right.$ pyrrolic $)$. MS-ESI: $m / z 451.15[\mathrm{M}+\mathrm{Na}]^{+}$.

\subsubsection{2-(1-(3-Fluorophenyl)-2-methyl-5-(4-sulfamoylphenyl)-} 1H-pyrrol-3-yl)- $\mathrm{N}$-isopropylacetamide (11). $\quad{ }^{1} \mathrm{H} \quad \mathrm{NMR}$ $\left(400 \mathrm{MHz}\right.$, DMSO- $\left.d_{6}\right) \delta \mathrm{ppm}: 7.81(\mathrm{~d}, 1 \mathrm{H}, \mathrm{NH}), 7.58(\mathrm{~d}, 2 \mathrm{H}$, $-\mathrm{C}-\mathrm{CH}-\mathrm{CH}), 7.48-7.46(\mathrm{~m}, 1 \mathrm{H}, \mathrm{CH}-\mathrm{CH}-\mathrm{CH}), 7.32-7.30(\mathrm{~m}, 1 \mathrm{H}, \mathrm{N}-$ $\mathrm{C}-\mathrm{CH}-\mathrm{CH}$ ), 7.25 (s broad, $2 \mathrm{H}, \mathrm{SO}_{2} \mathrm{NH}_{2}$ ), 7.21-7.18 (m, $1 \mathrm{H}, \mathrm{N}-\mathrm{C}-$ $\mathrm{CH}-\mathrm{C}-\mathrm{F}$ ), 7.12 (d, 2H, S-C-CH-CH), 7.01 (d, 1H, CH-CH-C-F), 6.43 (s, $1 \mathrm{H}, \mathrm{CH}$ pyrrolic), 3.85-3.79 (set, $1 \mathrm{H}, \mathrm{CH}_{3}-\mathrm{CH}-\mathrm{CH}_{3}$ ), 3.20 (s, 2H, C-CH $-\mathrm{CO}$ ), 1.98 (s, 3H, $\mathrm{CH}_{3}$ pyrrolic), 1.06 (d, 6H, CH$\left.\mathrm{CH}_{3}\right) .{ }^{13} \mathrm{C}$ NMR $\left(100 \mathrm{MHz}, \mathrm{DMSO}-d_{6}\right) \delta(\mathrm{ppm}): 171.3(\mathrm{CO}-\mathrm{O})$, $164.2(\mathrm{C}-\mathrm{F}), 143.7(\mathrm{~S}-\mathrm{C}), 143.5(\mathrm{~N}-\mathrm{C}-\mathrm{CH}), 143.0(\mathrm{CH}-\mathrm{C}-\mathrm{CH})$, $134.4(\mathrm{~N}-\mathrm{C}-\mathrm{C}), 131.3(\mathrm{CH}-\mathrm{CH}-\mathrm{CH}), 130.0(\mathrm{CH}-\mathrm{C}-\mathrm{S}), 127.9(\mathrm{C}-$ $\mathrm{CH}-\mathrm{CH}), 126.2\left(\mathrm{~N}-\mathrm{C}-\mathrm{CH}_{3}\right), 121.6\left(\mathrm{C}-\mathrm{CH}_{2}\right), 117.1(\mathrm{~N}-\mathrm{C}-\mathrm{CH}-\mathrm{CH})$, 113.1 ( $\mathrm{CH}$ pyrrolic), $112.2(\mathrm{CH}-\mathrm{CH}-\mathrm{C}-\mathrm{F}), 107.5$ (F-C-CH-C-N), $44.3(\mathrm{NH}-\mathrm{CH}), 34.5\left(\mathrm{CH}_{2}-\mathrm{CO}\right), 23.1\left(\mathrm{CH}-\mathrm{CH}_{3}\right), 9.8\left(\mathrm{CH}_{3}\right.$ pyrrolic $)$. MS-ESI: $m / z 452.14[\mathrm{M}+\mathrm{Na}]^{+}$.

4.1.7.4. 2-(1-(4-Fluorophenyl)-2-methyl-5-(4-sulfamoylphenyl)$\mathbf{1 H}$-pyrrol-3-yl)- $\mathbf{N}$-isopropylacetamide (12). White powder, mp $194{ }^{\circ} \mathrm{C}$ (yield 60\%). ${ }^{1} \mathrm{H}$ NMR (400 MHz, DMSO- $\left.d_{6}\right) \delta$ ppm: 7.78 $(\mathrm{t}, 1 \mathrm{H}, \mathrm{NH}), 7.57(\mathrm{~d}, 2 \mathrm{H},-\mathrm{C}-\mathrm{CH}-\mathrm{CH}), 7.29-7.25$ (m, $4 \mathrm{H}, \mathrm{H}$ aromatic), 7.23 (s broad, $2 \mathrm{H}, \mathrm{SO}_{2} \mathrm{NH}_{2}$ ), 7.10 (d, 2H, S-C $\left.-\mathrm{CH}-\mathrm{CH}\right), 6.41(\mathrm{~s}, 1 \mathrm{H}$, $\mathrm{CH}$ pyrrolic), 3.84-3.79 (set, $\left.1 \mathrm{H}, \mathrm{CH}_{3}-\mathrm{CH}-\mathrm{CH}_{3}\right), 3.19$ (s, $2 \mathrm{H}, \mathrm{C}-$ $\mathrm{CH}_{2}-\mathrm{CO}$ ), 1.98 (s, 3H, $\mathrm{CH}_{3}$ pyrrolic), 1.05 (d, $\left.6 \mathrm{H}, \mathrm{CH}-\mathrm{CH}_{3}\right) \cdot{ }^{13} \mathrm{C}$ NMR (100 MHz, DMSO-d $\left.d_{6}\right) \delta$ (ppm): 171.3 (CO-O), 159.7 (C-F), $147.2(\mathrm{~N}-\mathrm{C}-\mathrm{CH}), 143.5(\mathrm{~S}-\mathrm{C}), 142.8(\mathrm{CH}-\mathrm{C}-\mathrm{CH}), 134.3(\mathrm{~N}-\mathrm{C}-\mathrm{C})$, $129.2(\mathrm{CH}-\mathrm{C}-\mathrm{S}), \quad 127.7$ (C-CH-CH), $126.4\left(\mathrm{~N}-\mathrm{C}-\mathrm{CH}_{3}\right), \quad 122.3$
(N-C-CH-CH), $121.2\left(\mathrm{C}-\mathrm{CH}_{2}\right.$ pyrrolic), $116.3(\mathrm{CH}-\mathrm{CH}-\mathrm{C}-\mathrm{F}), 113.3$ (CH pyrrolic), $44.5(\mathrm{NH}-\mathrm{CH}), 34.8\left(\mathrm{CH}_{2}-\mathrm{CO}\right), 23.2\left(\mathrm{CH}-\mathrm{CH}_{3}\right), 10.0$ $\left(\mathrm{CH}_{3}\right.$ pyrrolic). MS-ESI: $m / z 452.14[\mathrm{M}+\mathrm{Na}]^{+}$.

\subsection{Biology and pharmacology}

\subsubsection{In vitro anti-inflammatory studies}

The inhibitory activity of compounds 1-12 against both cyclooxygenases, COX-1 and COX-2, was determined by the commercially available COX Inhibitor Screening Assay (Cayman Chemical, Ann Arbor, MI, USA, catalogue no. 560131), which exploits an enzyme immunoassay to measure $\mathrm{PGE}_{2 \mathrm{a}}$ produced by stannous chloride reduction of $\mathrm{PGEH}_{2}$, derived in turn by reaction between the target enzyme and the substrate, arachidonic acid. According to manufacture's protocol, test compounds $(10 \mu \mathrm{L})$ were incubated for $10 \mathrm{~min}$ at $37^{\circ} \mathrm{C}$ with assay buffer $(0.1 \mathrm{M}$ Tris- $\mathrm{HCl}, \mathrm{pH} 8,160 \mu \mathrm{L})$, Heme $(10 \mu \mathrm{L})$, and either ovine COX-1 or human recombinant COX-2 enzyme solution $(10 \mu \mathrm{M})$. Arachidonic acid $(10 \mu \mathrm{L})$ was then added, and the resulting mixture was incubated for $2 \mathrm{~min}$ at $37^{\circ} \mathrm{C}$. Enzyme catalysis was stopped by adding $\mathrm{HCl}(1 \mathrm{M}, 10 \mathrm{~mL})$ and the obtained $\mathrm{PGEH}_{2}$ were converted to $\mathrm{PGE}_{2 \mathrm{a}}$ with saturated stannous chloride solution $(20 \mu \mathrm{L})$. Prostanoids were finally quantified by EIA and their amount was determined through interpolation from a standard curve. The \% inhibition of target enzyme by test compounds was calculated by comparing $\mathrm{PGE}_{2 \mathrm{a}}$ produced in compound-treated samples with that of the compound-free, control sample. The highly selective COX-1 inhibitor SC-560 and the highly selective COX-2 inhibitor Dup-697 were used as reference compounds. All the test compounds, 1-12, were dissolved into dilute assay buffer, and their solubility was facilitated by using DMSO, whose concentration never exceeded $1 \%$ in the final reaction mixture. The inhibitory effect of test compounds was routinely estimated at a concentration of $10 \mu \mathrm{M}$. Those compounds found to be active were tested at additional concentrations between $10 \mu \mathrm{M}$ and $10 \mathrm{nM}$. The determination of the $\mathrm{IC}_{50}$ values was performed by linear regression analysis of the log-dose response curve, which was generated using at least five concentrations of the inhibitor causing an inhibition between $10 \%$ and $90 \%$, with three replicates at each concentration (Table 1).

\subsubsection{In vivo analgesic and anti-inflammatory study}

The analgesic activity of compounds was assessed by performing the abdominal constriction test, using mice Male Swiss albino mice (23-25 g) and Sprague-Dawley or Wistar rats (150-200 g). The animals were fed with a standard laboratory diet and tap water ad libitum and kept at $23\left(1{ }^{\circ} \mathrm{C}\right.$ with a $12 \mathrm{~h}$ light/dark cycle, light on at 7 a.m.). Mice had been injected intra-peritoneal (ip) with a $0.6 \%$ solution of acetic acid $(10 \mathrm{~mL} / \mathrm{kg})$. The number of stretching movements was counted for $10 \mathrm{~min}$, starting $5 \mathrm{~min}$ after administration.

\subsection{Molecular modeling}

Any calculation was performed using a 6 blade ( 8 Intel-Xeon E5520 $2.27 \mathrm{GHz}$ CPU and 24 GB DDR3 RAM) running Debian GNU/Linux "Wheezy" 7.564 bit operating system.

\subsubsection{Molecular docking}

Molecular docking calculations were carried out with several programs selected among those as open source or free to academics: Autodock, ${ }^{26}$ Vina, $^{27}$ Plants, ${ }^{28}$ PARADOCKS ${ }^{29}$ and SurflexDock. $^{20}$

\subsubsection{Docking assessment protocol}

A cross-docking protocol was set up for eight docking program/ scoring function combination, during the cross-docking each 
ligand extracted from the experimental COX complex was docked into all the not native proteins for each isoenzyme.

\subsubsection{Ligand and protein preparation}

The experimental complexes (PDB entries listed in Tables 3 and $4),{ }^{22}$ upon hydrogen addition, were minimized by means of GROMACS $^{30}$ with the AMBER force field59 in explicit water (box expanding $10 \AA$ from each external complex coordinate) using the Powell method with an initial Simplex optimization (500 iterations) followed by 1000 iterations of conjugated gradient termination at $0.01 \mathrm{kcal} /(\mathrm{mol} \AA)$. Ligand's random conformations were generated from the bound conformation extracted from the minimized COX-1/COX-2 experimental co-crystallized complexes. Using OpenBabel 2.3.2 ${ }^{31}$ version, hydrogen atoms were added, and charges were loaded using the Gasteiger and Marsili charge calculation method, then their center of mass were centered at $x, y, z \quad 0.0$ coordinates, finally the OpenBabel obconformer tools was used to generate a minimized random conformation for each ligand. Input ligands file format was mol2 for all the docking programs except for Autodock and Vina that required a pdbqt format; a total of 8 docking/scoring function combinations were used.

\subsubsection{AutoDock/Vina setting}

Intermediary steps, such as pdbqt files for protein and ligand preparation were completed using different AutoDock Tools (ADT) Scripts. AutoGrid was used for the preparation of the grid map using a grid box. The grid size was expanded $10 \AA$ beyond any external ligand atoms with grid spacing of $0.375 \AA$ and centered at the mean molecules' center of mass. For each calculation, twenty poses were obtained and ranked according to the scoringfunctions of either Autodock or Vina.

\subsubsection{Plants settings}

The docking of the target protein with the ligand was performed using Plants v1.2 version with three different scoring functions at default speed (SPEED1). The docking tools generated 20 conformation for each docked ligand. The docking binding site was centered the molecules' mean center and enlarging to a radius of $15 \AA$.

\subsubsection{Paradocks settings}

Both Paradocks-pscore and Paradocks-pmf04 scoring functions were used in their default configuration (Iteration 15,000, particle count 20 , constricting the inertia start 1.0 , constricting inertia end 0.2 , cognitive weight 1.0 and social weight 3.4 ).

\subsubsection{Surflex-Dock settings}

Version 2.0.1 of the program was used; the input file was built using the mol2 prepared protein structure. The protocol was generated using all the ligands structures with a threshold of 0.50 and bloat set to 0 (default settings). Ligand were prepared as describes above and docked as mol2 files.

\subsubsection{New COX inhibitor preparation and docking}

Ligand's 3D conformations were generated from scratch. Marvin was used for drawing, displaying and characterizing chemical structures, Marvin 14.7.7.0, 2014, ChemAxon (http://www. chemaxon.com). For homogeneity purposes, OpenBabel was used to generate a random conformation similarly as described in the docking assessment section.

The 1-12 generated random conformations were cross-docked using Surflex-Dock and Vina for COX-1 and COX-2, respectively. The same setting used for the docking assessment protocol were applied. All the protein structures were used in this step.

\section{Acknowledgments}

R.R. acknowledges Italian Minister of University and Research (MIUR) (PRIN Grant. 20105YY2HL_003).

\section{Supplementary data}

Supplementary data associated with this article can be found, in the online version, at http://dx.doi.org/10.1016/j.bmc.2014.12.041.

\section{References and notes}

1. Bakhle, Y. S. Drugs Today 1999, 35, 237.

2. Xu, L.; Stevens, J.; Hilton, M. B.; Seaman, S.; Conrads, T. P.; Veenstra, T. D.; Logsdon, D.; Morris, H.; Swing, D. A.; Patel, N. L.; Kalen, J.; Haines, D. C.; Zudaire, E.; Croix, B. S. Sci. Transl. Med. 2014, 6, 242 ra84.

3. FitzGerald, G. A.; Patrono, C. N. Engl. J. Med. 2001, 345, 433.

4. McGettigan, P.; Henry, D. JAMA 2006, 296, 1633.

5. Liu, J.-Y.; Li, N.; Yang, J.; Li, N.; Qiu, H.; Ai, D.; Chiamvimonvat, N.; Zhu, Y.; Hammock, B. D. Proc. Natl. Acad. Sci. 2010, 107, 17017.

6. Biava, M.; Porretta, G. C.; Cappelli, A.; Vomero, S.; Manetti, F.; Botta, M.; Sautebin, L.; Rossi, A.; Makovec, F.; Anzini, M. J. Med. Chem. 2005, 48, 3428.

7. Biava, M.; Porretta, G. C.; Poce, G.; Supino, S.; Forli, S.; Rovini, M.; Cappelli, A.; Manetti, F.; Botta, M.; Sautebin, L.; Rossi, A.; Pergola, C.; Ghelardini, C.; Vivoli, E.; Makovec, F.; Anzellotti, P.; Patrignani, P.; Anzini, M. J. Med. Chem. 2007, 50, 5403.

8. Biava, M.; Porretta, G. C.; Poce, G.; Supino, S.; Manetti, F.; Forli, S.; Botta, M.; Sautebin, L.; Rossi, A.; Pergola, C.; Ghelardini, C.; Norcini, M.; Makovec, F.; Giordani, A.; Anzellotti, P.; Cirilli, R.; Ferretti, R.; Gallinella, B.; La Torre, F.; Anzini, M.; Patrignani, P. Bioorg. Med. Chem. 2008, 16, 8072.

9. Anzini, M.; Rovini, M.; Cappelli, A.; Vomero, S.; Manetti, F.; Botta, M.; Sautebin, L.; Rossi, A.; Pergola, C.; Ghelardini, C.; Norcini, M.; Giordani, A.; Makovec, F.; Anzellotti, P.; Patrignani, P.; Biava, M. J. Med. Chem. 2008, 51, 4476.

10. Biava, M.; Porretta, G. C.; Poce, G.; Battilocchio, C.; Manetti, F.; Botta, M.; Forli, S.; Sautebin, L.; Rossi, A.; Pergola, C.; Ghelardini, C.; Galeotti, N.; Makovec, F.; Giordani, A.; Anzellotti, P.; Patrignani, P.; Anzini, M. J. Med. Chem. 2010, 53, 723.

11. Biava, M.; Porretta, G. C.; Poce, G.; Battilocchio, C.; Botta, M.; Manetti, F.; Rovini, M.; Cappelli, A.; Sautebin, L.; Rossi, A.; Pergola, C.; Ghelardini, C.; Galeotti, N.; Makovec, F.; Giordani, A.; Anzellotti, P.; Tacconelli, S.; Patrignani, P.; Anzini, M. Curr. Med. Chem. 2011, 18, 1540.

12. Battilocchio, C.; Poce, G.; Alfonso, S.; Porretta, G. C.; Consalvi, S.; Sautebin, L.; Pace, S.; Rossi, A.; Ghelardini, C.; Di Cesare Mannelli, L.; Schenone, S.; Giordani, A.: Di Francesco, L.; Patrignani, P.; Biava, M. Bioorg. Med. Chem. 2013, 21, 3695.

13. Khanna, I. K.: Yu, Y. Huff, R. M.; Weier, R. M.: Xu, X.; Koszyk, F. J.; Collins, P. W.; Cogburn, J. N.; Isakson, P. C.; Koboldt, C. M.; Masferrer, J. L.; Perkins, W. E.; Seibert, K.; Veenhuizen, A. W.; Yuan, J.; Yang, D.-C.; Zhang, Y. Y. J. Med. Chem. 2000, 43, 3168.

14. Meller, S. T.; Dykstra, C.; Grzybycki, D.; Murphy, S.; Gebhart, G. F. Neuropharmacology 1994, 33, 1471.

15. Smith, C. J.; Zhang, Y.; Koboldt, C. M.; Muhammad, J.; Zweifel, B. S.; Shaffer, A.; Talley, J. J.; Masferrer, J. L.; Seibert, K.; Isakson, P. C. Proc. Natl. Acad. Sci. 1998 95, 13313.

16. Seibert, K.; Masferrer, J. L.; Needleman, P.; Salvemini, D. Br. J. Pharmacol. 1996, $117,1016$.

17. Musmuca, I.; Caroli, A.; Mai, A.; Kaushik-Basu, N.; Arora, P.; Ragno, R. J. Chem. Inf. Model. 2010, 50, 662.

18. Caroli, A.; Ballante, F.; Wickersham, R. B.; Corelli, F.; Ragno, R. J. Chem. Inf. Model. 2014, 54, 970.

19. Ragno, R.; Frasca, S.; Manetti, F.; Brizzi, A.; Massa, S. J. Med. Chem. 2005, 48, 200.

20. Spitzer, R.; Jain, A. N. J. Comput. Aided Mol. Des. 2012, 26, 687.

21. Jain, A. N. J. Comput. Aided Mol. Des. 2007, 21, 281.

22. Steiner, T. Angew. Chem., Int. Ed. 2002, 41, 48

23. Ballante, F.; Ragno, R. J. Chem. Inf. Model. 2012, 52, 1674.

24. Ballante, F.; Musmuca, I.; Marshall, G. R.; Ragno, R. J. Comput. Aided Mol. Des. 2012, 26, 907.

25. Pettersen, E. F.; Goddard, T. D.; Huang, C. C.; Couch, G. S.; Greenblatt, D. M.; Meng, E. C.; Ferrin, T. E. J. Comput. Chem. 2004, 25, 1605.

26. Morris, G. M.; Huey, R.; Olson, A. J. In Current Protocols in Bioinformatics; John Wiley \& Sons Inc., 2002.

27. Trott, O.; Olson, A. J. J. Comput. Chem. 2010, 31, 455.

28. Korb, O.; Stützle, T.; Exner, T. E. J. Chem. Inf. Model. 2009, 49, 84.

29. Meier, R.; Pippel, M.; Brandt, F.; Sippl, W.; Baldauf, C. J. Chem. Inf. Model. 2010 $50,879$.

30. Van Der Spoel, D.; Lindahl, E.; Hess, B.; Groenhof, G.; Mark, A. E.; Berendsen, H. J. C. J. Comput. Chem. 2005, 26, 1701.

31. O’Boyle, N. M.; Banck, M.; James, C. A.; Morley, C.; Vandermeersch, T.; Hutchison, G. R. J. Cheminf. 2011, 3, 33. 